Preprints of the

Max Planck Institute for

Research on Collective Goods

Bonn 2013/7

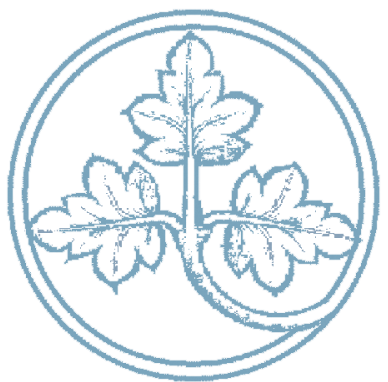

Who is Afraid of Pirates?

An Experiment on the

Deterrence of Innovation

by Imitation

Christoph Engel

Marco Kleine

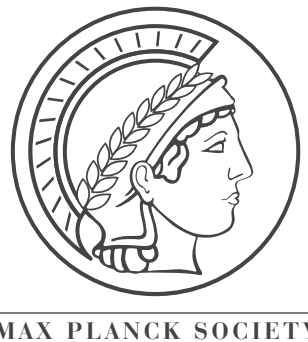




\section{Who is Afraid of Pirates? An Experiment on the Deterrence of Innovation by Imitation}

Christoph Engel / Marco Kleine

May 2013

revised November 2013 


\title{
Who is Afraid of Pirates? \\ An Experiment on the Deterrence of Innovation by Imitation ${ }^{*}$
}

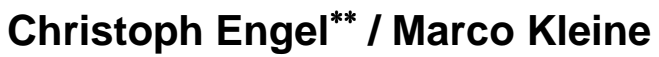

\begin{abstract}
In the policy debate, intellectual property is often justified by what seems to be a straightforward argument: if innovators are not protected against others appropriating their ideas, incentives for innovation are suboptimally low. Now in most industries for most potential users, appropriating a foreign innovation is itself an investment decision fraught with cost and risk. Nonetheless standard theory predicts too little innovation. Arguably the problem is exacerbated by innovators' sensitivity to fairness; imitators get a free lunch, after all.

We model the situation as a game and test it in the lab. We find more appropriation but also more innovation than predicted by standard theory. In the lab, the prospect of giving imitators a free lunch does not have a chilling effect on innovation. This even holds if innovation automatically spills over to an outsider, and if successful imitation reduces the innovator's profit. Post-experimental tests and the analysis of experiences in the repeated game demonstrate that participants are sensitive to the fairness problem. But this concern is not strong enough to outweigh the robust propensity to invest even more into innovation than predicted by standard theory. The data suggest that this behavior results from the intention not to be outperformed by one's peers.
\end{abstract}

JEL: C91, D22, D62, D63, H23, H41, K11, L17, O31

Keywords: innovation, imitation, appropriation, patent, fairness of desert

We are grateful for helpful comments by Rafael Aigner, Joshua Fairfield, Kal Raustiala and Lilia Zhurakhovska on an earlier version, and by discussion at the UCLA Law School, the Zentrum für Europäische Wirtschaftsforschung at Mannheim, and the Max Planck Institute for Research on Collective Goods at Bonn.

** corresponding author: Christoph Engel, Max-Planck-Institute for Research on Collective Goods, KurtSchumacher-Straße 10, D 53113 Bonn, Germany, ++49/228/9141610, engel@coll.mpg.de 


\section{Introduction}

A standard argument in favor of patent protection relies on the fact that knowledge tends to be non-excludable. Unless the law steps in and the patent creates a temporal monopoly, other users could just copy the invention. Anticipating this, nobody is willing to engage in costly innovation (for a typical voice see Menell and Scotchmer 2005:sec. IA). In its weaker and more realistic form, the argument expects investment into innovation to be suboptimally low if innovators are not protected against others tapping into their efforts.

This line of argument has long been criticized on empirical grounds. In many markets, the cost of imitation is pronounced. While the idea could also be used by others, competitors or not, if they want to appropriate it they would first have to engage in reverse engineering, they would have to change their production process or product, or they would have to invest into marketing the new product. Realistically, appropriating a foreign innovation is an investment decision itself, with its associated degree of uncertainty. Figure 1 illustrates this claim with survey data. ${ }^{1}$ It also shows that there is pronounced heterogeneity, both within and between industries.

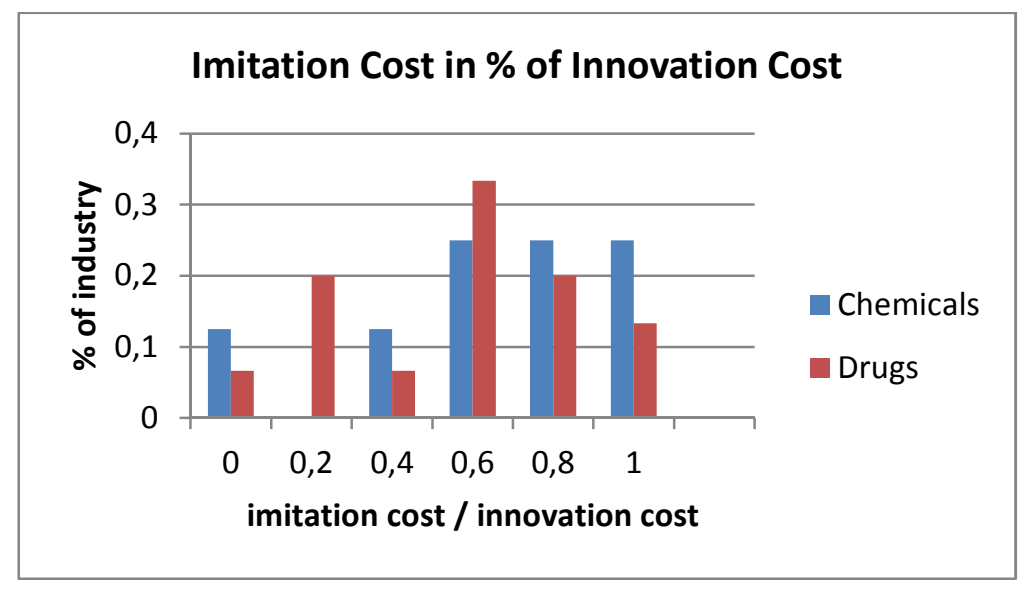

Figure 1

Imitation Cost

data from Mansfield et al. (1981)

$x$-axis: 0.8 means that the cost of imitation is $80 \%$ of the cost of innovation

$y$-axis: fraction of an industry that states imitation cost to be that high, relative to innovation cost

In the policy debate, it sometimes sounds as if the mere possibility of appropriation by others were to deter any innovation. ${ }^{2}$ At the opposite end of the spectrum, idealists equate appropriation of "intellectual property" with theft, ${ }^{3}$ and should consequently expect those tempted to be held back by moral compunctions. For either extreme position, the cost and the risk of appropriation are immaterial.

For further sources see below 0.

Take what Menell and Scotchmer (2005:sec. IA) define as "the economic problem": "Most firms would not invest in developing new technologies, and potential creators might not spend their time on creative works, if rivals could enter the market and dissipate the profit."

3 See, e.g. http://www.idearights.com/ideatheft.htm. 
If all actors are fully rational money maximizers, and if all of them anticipate all others to hold the same preferences, none of these extreme positions is supported. The theoretical prediction hinges on the expected individual profitability of innovation on the one hand, and of appropriation on the other hand. In equilibrium, actors split their resources between innovation and imitation. Standard theory therefore predicts the policy problem to be much more contained. Yet if all actors hold standard preferences, there is too little investment into innovation, compared with the social optimum.

From a behavioral perspective, the policy problem might loom even larger. If innovation is not protected, successful innovators expose themselves to exploitation. Others tap into their efforts without having contributed to the cost. Investors might consider such impingement as unfair and invest even less into innovation than predicted by standard theory.

Studying this question in the field would be difficult, if not impossible. The ease and the cost by which outsiders may appropriate innovations is not randomly assigned, which would be necessary for identification. In this paper, we therefore investigate the behavioral concern experimentally. We introduce a two-person game of two stages. In the first stage each player may invest into her own innovation project. She learns whether her own project and her counterpart's project have been successful. In the second stage, she may invest into appropriating her counterpart's project, provided it has been successful. We make innovation risky, and manipulate the conditions for appropriation. In the Low Risk treatment, appropriation is risky (and costly), but the risk of not succeeding to appropriate a foreign innovation is small. In the High Risk treatment, this risk is pronounced.

In our data, the concern of suboptimally low innovation investments is not supported. Both in a one-shot game and in the subsequent repeated game, participants invest significantly more, not less than predicted by standard theory.

To understand what drives this surprising result, we elicit beliefs and participants' attitude towards the fairness norm of desert. The more participants believe their counterpart will try to appropriate innovation success, the less they invest. The more they are willing to give in a dictator game to a recipient who could earn money by her own efforts, the more they invest into innovation. In the repeated game they reduce investment into innovation the more they learn that their counterpart has invested into appropriating their innovation in the previous period. All of this suggests that participants are actually sensitive to the fairness concern, that this sensitivity is only not strong enough to create a policy problem.

To better understand driving forces and to show the robustness of our finding that innovation investment is high even if the innovation is open to appropriation, we run two supplementary treatments. In these treatments, we radicalize the fairness concern. In the FullRisk treatment, imitation is technically excluded (the risk of not succeeding to appropriate the foreign innovation is infinite). In the NoRisk treatment, successful innovation is automatically shared with a second participant. If innovators dislike that outsiders benefit without contributing to the cost 
of innovation, we should see a monotonic relationship. There should be most innovation investment in the FullRisk case, less in the HighRisk case, even less in the LowRisk case, and least in the NoRisk case. This is the result suggested by a motive that features prominently in the behavioral literature, inequity aversion. Inequity aversion is exclusively concerned with relative payoff. While this seems a good explanation for quite a few experimental findings, other findings are better explained by perceived intentions. Our two additional treatments give us the possibility to discriminate between these two explanations. If intentions are critical, we should see less innovation in LowRisk than in NoRisk, potentially even less innovation in HighRisk than in NoRisk. We find clear evidence in favour of the intention story. There is more, not less investment into innovation if success is automatically shared with a second individual that has not contributed to the cost. Strikingly, innovation investment is as intense if an outsider automatically benefits, compared with a situation where imitation is totally excluded.

The situation of our main experiment is not uncommon in the field. My innovation may be of use in markets where I do not sell my products. Yet from a policy perspective the situation is of course even more important where innovative success also gives me a competitive advantage. Then successful appropriation has a direct drawback. I lose some of the gains from innovation for myself. In that situation, pecuniary drawback combines with hurt feelings of fairness. To study in which ways this combination of motives is detrimental, we run another two treatments. In a $2 \times 2$ factorial design we keep the appropriation functions from the LowRisk and HighRisk treatments, but change gains from innovation. In the LowAppr and HighAppr treatments, if appropriation is not attempted or fails, my gains from successful innovation are as in the main experiment. Yet they are lower if the second player successfully appropriates the innovation. We have another striking finding: the fact that the innovator's profit is affected does not reduce innovation investment either. Participants are still sensitive to the fairness problem. But this sensitivity is not more pronounced. This is even stronger support for the intention story. All participants care about is whether others intend to impinge on their efforts. But even if that is the case, this does not lead to underinvestment into innovation.

We finally offer an explanation for our very robust finding that participants overinvest into innovation. Our data suggest that this results from a competitive motive. Participants do not want to fall behind the innovation efforts of their peers. This effect is the more pronounced, the more a participant is averse to risk.

The remainder of the paper is organized as follows: section II relates our experiment to the literature on intellectual property policy, and to the existing empirical and experimental literature. Section III covers the main experiment, i.e. treatments LowRisk and HighRisk. Section IV adds the two treatments where appropriation is either excluded or complete and automatic, i.e. treatments FullRisk and NoRisk. Section V adds the final two treatments where appropriation reduces the innovator's profit, i.e. treatments LowAppr and HighAppr. Section VI offers an explanation for overinvestment into innovation. Section VII concludes with discussion. 


\section{Related Literature}

The standard argument in favor of patent protection is, for instance, made by United States Government Accountability Office (2010). It has been criticized on theoretical grounds. It has been claimed that innovation is often a process rather than an isolated event. Then an imitator does not just copy, but uses the earlier innovation to make the next innovative step, which is made difficult by patent protection (Heller and Eisenberg 1998; Aghion et al. 2001; Mukoyama 2003; Bessen and Maskin 2009). If a firm's success depends on its R\&D intensity, the subsidy inherent in patent protection reduces overall innovative activity and hence growth (Segerstrom 1991; Grossman and Helpman 1992; Davidson and Segerstrom 1998). Depending on payoffs from innovation and imitation, the resulting static game may not be a prisoner's dilemma (Engel 2011), and the deadweight loss resulting from the monopoly over knowledge may outweigh the social benefit from the stronger innovation incentive (Kaplow 1984). Empirically, protection is never perfect, which is why patent might be better modeled as a probabilistic right (Lemley and Shapiro 2005).

One major counterargument stresses that, in the field, new technological knowledge is often not a pure public good. Not only for creating, but also for using it, tacit knowledge is necessary that is, at least initially, only possessed by the innovator. Even if that is not the case, imitators often face a positive cost of appropriation, and innovators have some lead time (Cimoli et al. 2011). Empirical studies have found imitation cost to be pronounced in many industries. It not so rarely even exceeds innovation cost, but industry characteristics are critical (Mansfield et al. 1981). In the well-known Yale Survey, 650 respondents from various industries rated patent protection to be the least important measure for securing a competitive advantage, while they on average put most stress on lead time, followed by going down the learning curve quickly, being good at sales and service, and secrecy. Again there were pronounced differences between industries, though, with producers of drugs and chemicals seeing patent as most important (Levin et al. 1987). In the subsequent Carnegie Mellon Survey, the estimated disadvantage of patent was less pronounced. But patent was still outperformed by secrecy and lead time (Cohen et al. 2000). Similar findings have been made for Germany, Portugal (Faria and Sofka 2010), Switzerland (Harabi 1994) and the US, but not for Japan (Cohen et al. 2002). On average, patent protection only prolongs the imitation lag by a few months (Cohen et al. 2002).

Note that the evidence on the comparative importance of protection technologies asks how "important" patent is. This evidence thus not only measures the ex post cost of imitation. It also speaks to the chilling effect resulting from imperfect or entirely missing patent protection. Apparently, industry representatives also do not deem patent particularly important from the ex ante perspective of engaging in innovation. Whole industries like fashion, food, standup comedy or sports are not protected by property rights for creativity, and still all of them are rife with innovation (Raustiala and Sprigman 2012). 
Lab experiments on innovation and intellectual property rights have focused on different issues. The closest analogue is Suetens (2005). She had participants in a duopoly repeatedly decide how much to invest into risky innovation. New knowledge was either completely protected, or could be used at zero cost by the other player. Absent institutional intervention, results were closest to the Nash predictions. If knowledge was protected, only binding (collusive) contracts helped participants reduce overinvestment. If knowledge was not protected, cheap talk was even more effective in mitigating underinvestment than a contract. She also finds investment into innovation above the Nash prediction if innovation is not protected. The main difference to our approach stems from our focus on fairness as a potential deterrent of innovation. Moreover in line with field evidence, we make imitation costly and risky, and thereby have participants choose between innovation and imitation. We also test different degrees of success probability for appropriation, we manipulate whether appropriation has a negative effect on the innovator's payoff and we generate explanatory variables through postexperimental tests.

Diduch (2010) uses a setting similar to Suetens (2005) for a classroom experiment. Darai et al. (2009) offer members of an experimental triopoly either no additional incentive for engaging in risky and costly process innovation, a subsidy or a property right. They find overinvestment in all treatments, higher investment with either intervention, and no significant difference between both interventions. Isaac and Reynolds (1992) show that there is more R\&D with competition than with a monopoly. Suetens (2008) finds that cooperative investment facilitates tacit price collusion. Deck and Erkal (2012) find that research cooperation falters the closer firms move to success. Cantner et al. (2009) use a naturalistic setting to have members of a random duopoly engage in a patent race. They find interaction driven by the fact that either competitor uses a bold or a cautious strategy. Sbriglia and Hey (1994); Zizzo (2002); Silipo (2005) also study patent races in the lab. Bäker et al. (2011) investigate the impact of creativity, analytic skills and personality traits on innovation behavior. Ullberg (2010b) experimentally investigates trade in licences. Ullberg (2010a) explores whether patenting serves as a signal for the productivity of inventive efforts in a technology.

\section{High Investments Despite of Giving Others a Free Lunch}

\section{Design and Procedures}

To test the competing expectations, we run a lab experiment. Participants are randomly assigned to groups of two. Every player has an endowment $e=20$ tokens, which she can keep or invest into one of two purposes: innovation or appropriation. Investment is sequential, with the innovation stage preceding the appropriation stage.

Specifically in the first stage each player, $i$ decides how much of her endowment $e$ to invest into an (innovation) project. Innovation is costly and risky. The probability of success of a project increases with contribution $c_{i}$ the tokens invested into the project, according to the following logistic probability function: 


$$
\operatorname{prob}=\frac{c_{i}}{1+c_{i}}
$$

This creates a function as in Figure 2. The first token invested sets the probability of success to $50 \%$. With all 20 tokens invested, this probability is at $95.24 \%$. We thus implement an innovation function with decreasing (expected) returns to investment.

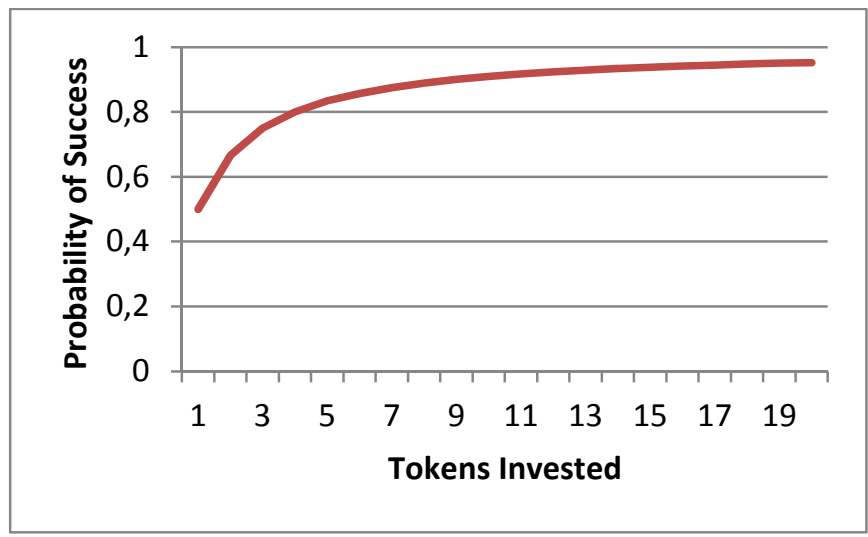

Figure 2

Probability Function at Innovation Stage

If the project is successful, the player reaps gain $g_{i}=40$ tokens. At the beginning of the second stage each player is informed about the success of her own project, as well as her counterpart's investment and the success of the foreign project. Out of the remaining endowment (i.e. endowment minus tokens invested at stage 1) players may at this stage invest into appropriation of the project of their counterpart. For appropriation, we implement two levels of uncertainty of success: a low risk of failure (LowRisk treatment), or a high risk of failure (HighRisk treatment). Probability functions are logistic and given by

$$
\text { prob }=\frac{\frac{a_{i}}{y_{i}}}{1+\frac{a_{i}}{y_{i}}}
$$

with $a_{i}$ being the tokens invested into appropriating the counterpart's innovation. Parameter $y_{i}$ is equal to 1 in the LowRisk treatment. In this condition, the probability functions for innovation in stage 1 and appropriation in stage 2 are hence the same. Parameter $y_{i}$ is equal to 10 in the HighRisk treatment. With HighRisk, one token invested leads to $9.1 \%$ probability of successful appropriation, while 20 tokens invested push this probability up to $66.66 \%$. Expected returns from appropriation thus also decrease in investment. In the LowRisk environment, appropriation is "easy and cheap", in the HighRisk environment, appropriation is "difficult and costly". Figure 3 summarizes the treatment manipulation. 


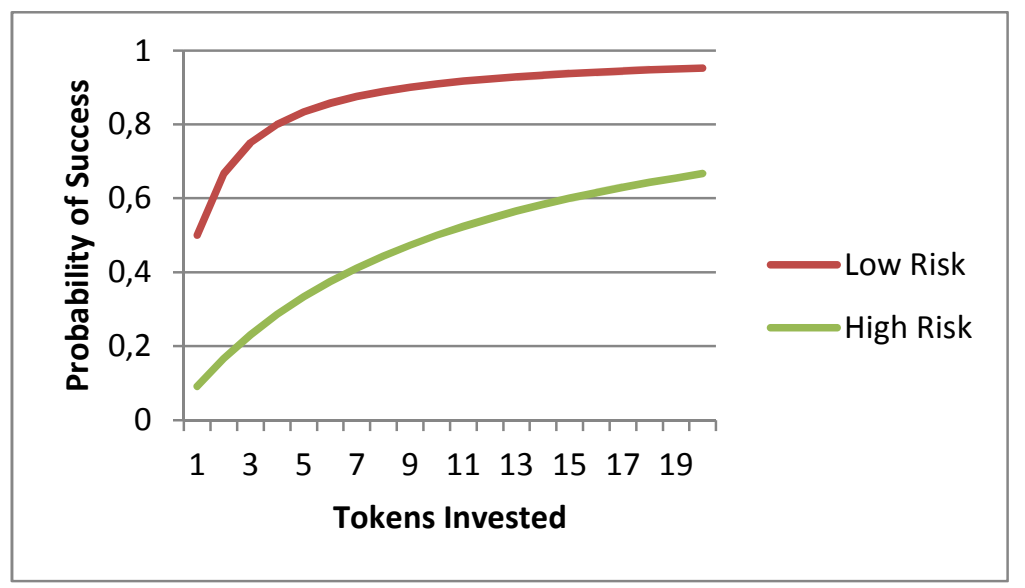

Figure 3

Treatments: Probability of Appropriation Success

The player whose appropriation is successful reaps gains of $\beta g_{i}$.In our experiment the degree of appropriability $\beta$ equals 0.9 , which means that successful appropriation accounts for gains $\beta g_{i}=36$ tokens. Note that gains from appropriation are conditional on the success of the counterpart's project of the first stage.

Expected profit is hence given by

$$
\pi_{i}=e-c_{i}-a_{i}+\frac{c_{i}}{1+c_{i}} g_{i}+\beta \frac{\frac{a_{i}}{y}}{1+\frac{a_{i}}{y}} \frac{c_{j}}{1+c_{j}} g_{j}
$$

This constitutes a linear public good, with four features meant to capture the essence of the patent problem: [1] returns from investment are not deterministic, but probabilistic; [2] the second agent does not automatically benefit from contributions by the first agent, but has to invest into appropriation; [3] appropriation is not deterministic, but probabilistic; [4] appropriation is never complete.

To make sure participants have understood the game, we both provide them with a table translating investment into a probability of success, and we give them a graphical representation. For detail, readers are referred to the translated instructions in the appendix.

We have chosen parameters such that innovators with standard preferences always have enough money for appropriation, and vice versa. If they stop investing into innovation once the marginal benefit from investing another unit of their endowment into innovation is below 1 , they still have enough of their endowment to independently decide how much to invest into appropriation of their counterpart's project, should it have been successful. That way we can attribute levels of innovation below the theoretical benchmark to innovators' reticence to give others a free lunch. By the choice of parameters, we also exclude another potential confound. If we were to find less innovation than predicted by theory, we would be able to infer that this 
is because innovators dread exploitation, not because they want to keep enough resources for being exploiters themselves.

While we implement a sequential game, with an investment stage followed by an appropriation stage, a player holding standard preferences must decide at the first stage how to split her endowment between innovation, (a chance for) appropriation, and money she intends to keep. We do not give a successful innovator the possibility to use the profit for appropriating a foreign innovation. This design choice is motivated by external validity. Typically, marketing an innovation takes time. Before the innovation has translated into higher profit, banks are unlikely to monetarize the value of the innovation, since the value of pure knowledge is hard to quantify.

We also do not give a successful innovator a chance to invest into defending her innovation against appropriation. This design choice is motivated by the desire to induce a clean choice for appropriation. That way we also avoid adding a third stage to the game.

In our game, payoffs directly follow from investments. There is no demand side, and no market on which innovators compete. This simplification not only makes it easier to implement the game in the lab. It more importantly helps us isolate the effect we are interested in. Had we played out the market stage, when deciding upon investment fully prevoyant participants would have had to anticipate how the odds for collusion in the market are affected by investment, or investment success. If we had found little innovation investment, we would not have known whether this is due to the fact that participants dread appropriation, or whether they are afraid that the resulting asymmetry of earnings (or efficient quantity choices) would make it more difficult to establish collusion. Note that modeling new knowledge as a pure public good implicitly makes the same choice.

In our experiment, there is no room for trade. If I have been successful, while another participant's efforts have been futile, she cannot buy a license to use my innovation. Had we allowed for trade, we would have changed the game into one where two firms may share the risk of invention.

At the beginning of the experiment, the game is played once. Participants only know that the experiment has further parts, but they do not know what later parts are about. This design feature provides us with a clean test for behavior in a one-shot game, and makes it impossible for participants to decide under the shadow of the future. After the end of part 1, and before giving participants feedback about the appropriation stage 2, we elicit beliefs about appropriation. We pledge a bonus if participants correctly estimate the fraction of participants who decide to appropriate foreign investments, and the mean size of the investment. For the sake of keeping observations independent across matching groups, we withhold feedback on this auxiliary task until the end of the experiment.

To investigate whether effects change with experience, we then repeat the stage game 10 announced times. We implement a stranger protocol. Following the procedure that is standard in 
the experimental literature (see e.g. Charness 2000; Montero et al. 2008), we assign participants to matching groups of 6 , but do only tell them they will be re-matched every period, not that matching groups have limited size. This procedure is meant to guarantee independent observations, without inducing participants to try to second guess group composition.

To the best of our knowledge, there is no standard test for fairness of desert. According to this fairness norm, the distribution of payoffs should reflect individual's effort or investment (cf. e.g. Gill and Stone 2010). Since participants' attitude towards this fairness norm may be key for understanding our results, we design the following new test: At the end of the experiment, we inform participants that they will be randomly matched to new pairs of two participants. Ex post, the computer will assign the role of dictator (neutrally framed as "active player") to one participant, and the passive role of recipient to the other. Using the strategy method (Selten 1967), we ask participants which fraction of their income of 125 tokens from this part of the experiment they want to give to the passive player, should they be the dictator. We have them decide for the four cases summarized in Table 1.

\begin{tabular}{|c|c|c|c|}
\hline & \multicolumn{2}{|c|}{ Recipient } \\
\hline & & no income & earned income \\
\hline \multirow{2}{*}{ dictator } & endowment & & \\
\hline & earned income & & \\
\hline
\end{tabular}

Table 1

Fairness of Desert Test

In the endowment cells, the dictator's endowment is given and need not be earned in a real effort task. In the no income cells the recipient has no income. In the earned income cells participants have to perform a real effort task and earn an income of 125 tokens.

For this test, we use the task developed by Mazar et al. (2008). For each token participants have to find the one pair of cells that adds up to 10, in matrices as in Table 2.

\begin{tabular}{|l|l|l|}
\hline 4.67 & 4.81 & 3.05 \\
\hline 5.82 & 5.06 & 4.28 \\
\hline 6.36 & 5.19 & 4.57 \\
\hline
\end{tabular}

Table 2

Task in Fairness of Desert Test

There is no time limit. But all earnings from the entire experiment are held back until a participant has correctly solved the required number of problems, to make sure that income is indeed earned. ${ }^{4}$

The experiment was conducted in the Cologne Econ Lab. The experiment was implemented in zTree (Fischbacher 2007). Participants were invited with the software ORSEE (Greiner 2004). Participants had to answer control questions to make sure they had understood the in-

$4 \quad$ We also elicit risk preferences, using the standard procedure by Holt and Laury (2002), and social preferences, using the standard procedure by Liebrand and McClintock (1988), but neither test turns out informative. 
structions. 120 students of various majors participated. In the one-shot game, choices are independent. In the repeated game, we have 20 independent observations. 65 participants $(54.17 \%)$ were female. Most of them were students, of various majors. Mean age was 25.99 years. At the end of the experiment earned tokens were converted into $€$ - for the main experiment with the conversion rate of $.02 € /$ token - and paid to the participants in cash. Participants on average earned $18.79 €(23.07 \$$ at the days of the experiment), range [10.49 $€$, $24.35 €]$. Sessions lasted about one and a half hours.

\section{Hypotheses}

In the policy debate, not so rarely the impression is conveyed that the legal protection of intellectual property is a precondition for any innovation. Specifically, it is claimed that no reasonable person, or firm for that matter, would invest money into the risky creation of new knowledge if potential users were free to pass by and use the innovation for their own benefit, without compensating the former agent for her efforts (see e.g. United States Government Accountability Office 2010). At first glance, this argument seems to be backed up by standard economic theory. If knowledge is a pure public good (Cornes and Sandler 1996), should this not be another instance of the tragedy of the commons (Hardin 1968)? In our experiment, there is no institutional protection of innovation success. If the concern sometimes voiced in the policy debate gets it right, we should find

$\mathbf{H}_{1}$ : a) There is no investment into innovation (and therefore nothing to appropriate).

b) There are no treatment differences.

Much of the policy debate has a moral undertone. If intellectual property goes unprotected, this is not only inefficient. It is also unjust. Intellectual property is property. Appropriating property without having contributed to its generation is theft, or so the argument goes (see again United States Government Accountability Office 2010). Such statements are not meant as contributions to an idealistic discourse. Labeling appropriation as theft hopes to trigger moral compunctions most people have against stealing tangible property. While, in the experiment, we of course do not use such value laden words, from the incentive structure it still is clear that appropriation is an act of tapping into foreign efforts. If morally grounded hesitance to do so is indeed as powerful as this policy discourse wants it, we should see

$\mathbf{H}_{2}$ : a) There is investment into innovation, but no investment into appropriation. b) There are no treatment differences.

Both claims from the policy debate of course ignore the main point of both the experiment and the situation in most industries: appropriating foreign knowledge is not free of charge, but costly and risky. If participants are risk neutral maximizers of payoff, each of the treatments constitutes a game. Each game has a unique equilibrium in pure strategies. Specifically, a money maximizing player reasons in three steps: [1] what would be the optimal investment into appropriation, provided the budget constraint does not bind? [2] what would be the opti- 
mal investment into innovation, again provided the budget constraint does not bind? [3] does the budget constraint bind? If so, how shall the player optimally trade a chance for innovation success against a chance for appropriation success?

Participants play a game of two stages. At the second stage, they have made an investment $c_{i}$ into innovation. If they learn that the investment of their counterpart has failed, they keep $e-c_{i}$. If their counterpart's investment has been successful, they decide how much to invest into appropriation.Any token kept gives them a sure gain of 1 . They thus invest into appropriation until the marginal expected gain is at or below 1 . They find this threshold by maximizing (2) with respect to $a_{i}$.

$$
\pi\left(a_{i}\right)=\frac{\frac{a_{i}}{y}}{1+\frac{a_{i}}{y}} \beta g_{j}-a_{i}
$$

, which yields $a^{*}=\sqrt{\beta g y}-y$. At the first stage participants must decide how much to invest into innovation. Provided the budget constraint does not bind, the opportunity cost of any token invested is again 1. Money maximizing participants invest into innovation until the marginal expected gain is at or below 1 . They find this threshold by maximizing (3) with respect to $c_{i}$

$$
\pi\left(c_{i}\right)=\frac{c_{i}}{1+c_{i}} g_{i}-c_{i}
$$

, which yields $c^{*}=\sqrt{g}-1$. The budget constraint binds provided $e<a_{i}^{*}+c_{i}^{*}$. We are not interested in the conflict between innovation and appropriation per se. Rather we want to learn whether the prospect of appropriation deters participants from innovating, even if this would be in their best interest. We are thus interested in the fairness problem resulting from the fact that unprotected innovation gives outsiders a free lunch. In the interest of isolating this effect, we choose parameters such that the budget constraint does not bind. Consequently, both at the appropriation and at the innovation stage, choosing the profit maximizing level of investment is a dominant strategy. Table 3 collects point predictions, assuming common knowledge of standard preferences.

\begin{tabular}{|c|c|c|c|c|c|c|}
\hline & \multicolumn{2}{|c|}{$\begin{array}{c}\text { Innovation } \\
\text { investment }\end{array}$} & \multicolumn{2}{c|}{$\begin{array}{c}\text { appropriation } \\
\text { investment }\end{array}$} & \multicolumn{2}{c|}{$\begin{array}{c}\text { endowment kept } \\
\text { (if foreign project succeeds) }\end{array}$} \\
\hline & Nash & Efficient & Nash & efficient & Nash & efficient \\
\hline LowRisk & 5.325 & 7.062 & 5.000 & 5.000 & 9.675 & 7.938 \\
\hline HighRisk & 5.325 & 5.932 & 8.974 & 8.974 & 5.701 & 5.094 \\
\hline
\end{tabular}

Table 3

Point Predictions

Given we implement a sequential structure, we expect

$\mathbf{H}_{3}$ : There are investments into innovation and appropriation as predicted in Table 3.

To get an intuition of the forces driving appropriation choices of participants holding standard preferences, consider Figure 4. With a few tokens, the expected benefit from investing anoth- 
er token into appropriation is huge in the Low Risk treatment, but it decays rapidly. In the High Risk treatment, the expected benefit of investing the first tokens is much smaller.

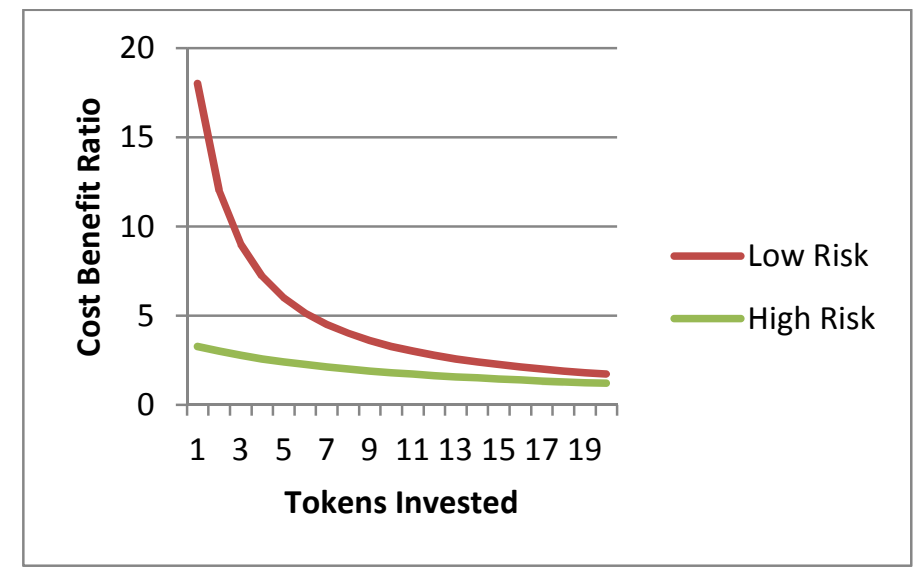

Figure 4

Expected Benefit per Token Invested Into Appropriation

Our experiment has been motivated by a behavioral concern. If I must expect that others appropriate my innovation, without contributing to the cost of innovation, this might reduce my willingness to invest into innovation. There are two different behavioral reasons why the risk of appropriation might deter innovation. The first motive results from payoff comparisons, as modeled by Bolton and Ockenfels (2000) and Fehr and Schmidt (1999). We use the second model since it almost has become an industry standard. According to this model, in a community of two individuals, utility is given by (4).

$$
u_{i}=\pi_{i}-\alpha \max \left\{\pi_{j}-\pi_{i}, 0\right\}-\beta \max \left\{\pi_{i}-\pi_{j}, 0\right\}
$$

I suffer disutility from falling behind my peer $(\alpha)$ and disutility from being ahead of my peer $(\beta)$. It is generally assumed that the former disutility is more pronounced than the latter. In general defining utility in terms of (4) is difficult in our setting. Payoff differences may result from differences in the success of innovation, in the decision to invest into appropriation and the associated probability of success, and in an imbalance of cost from total investment. Yet the critical issue is not calculating utility in absolute terms, but predicting treatment differences. In the HighRisk treatment, the other participant is technically able to create a payoff imbalance by appropriating successful innovation, but this requires high investment. By contrast, in the LowRisk treatment a small investment suffices to make appropriation probable. Since our manipulation holds everything else constant, we should expect that inequity aversion exacerbates the policy problem, the more so the lower the risk that appropriation efforts fail.

This leads to

$\mathbf{H}_{4}$ : a) Irrespective of treatment, innovation investment is below the Nash prediction.

b) Innovation investment is lower in the LowRisk treatment than in the HighRisk treatment. 
The behavioral downside of imitation could also have a different source. Appropriation is intentional by design. The appropriator tries to lay her hand on foreign success. This invites analysis in terms of a model of intentions. The canonical model by Rabin (1993) is very rich. For our purposes, the following simplified version suffices:

$$
u_{i}=\pi_{i}-\rho\left(a_{j}-\tilde{a}\right)\left(a_{i}-\tilde{a}\right)
$$

There is a socially acceptable level of appropriation a ; the simple most assumption is of course $\tilde{a}=0$ : the society of two participants is categorically opposed to appropriation. If I exceed the acceptable level, I am unkind, which gives me disutility. But I also lose utility if my partner oversteps the agreed-upon boundaries. Disutility from unkindness cancels out if we both disregard expectations, to the same degree.

This model also predicts that innovation investment is below the Nash benchmark, but it does not predict a treatment effect. For the LowRisk and the HighRisk treatments only differ in the effect, not in intentions. If intentions are critical, we therefore have the alternative hypothesis

$\mathbf{H}_{5}$ : a) Irrespective of treatment, innovation investment is below the Nash prediction.

b) There are no treatment differences.

\section{Results}

We first present results from the one-shot game, and investigate in the end in which ways results change with experience. Figure 5 first shows that, with both specifications of the appropriation technology, participants on average invest a substantial fraction of their endowments into innovation. Descriptively we clearly find no support for $\mathbf{H}_{1}$. Knowing that another anonymous participant will have an opportunity to lay her hand on one's innovation success does not completely deter participants from innovative activity. One sample sign rank tests refute the hypothesis of no investment into innovation at $\mathrm{p}<.0001$, both overall $(\mathrm{N}=120)$, and separately for each treatment $(\mathrm{N}=60) .{ }^{5}$ Actually we even reject the hypothesis in a Popperian sense: we do not observe a single participant who invests nothing into innovation.

$5 \quad$ All statistical tests reported in this paper are two-sided. 


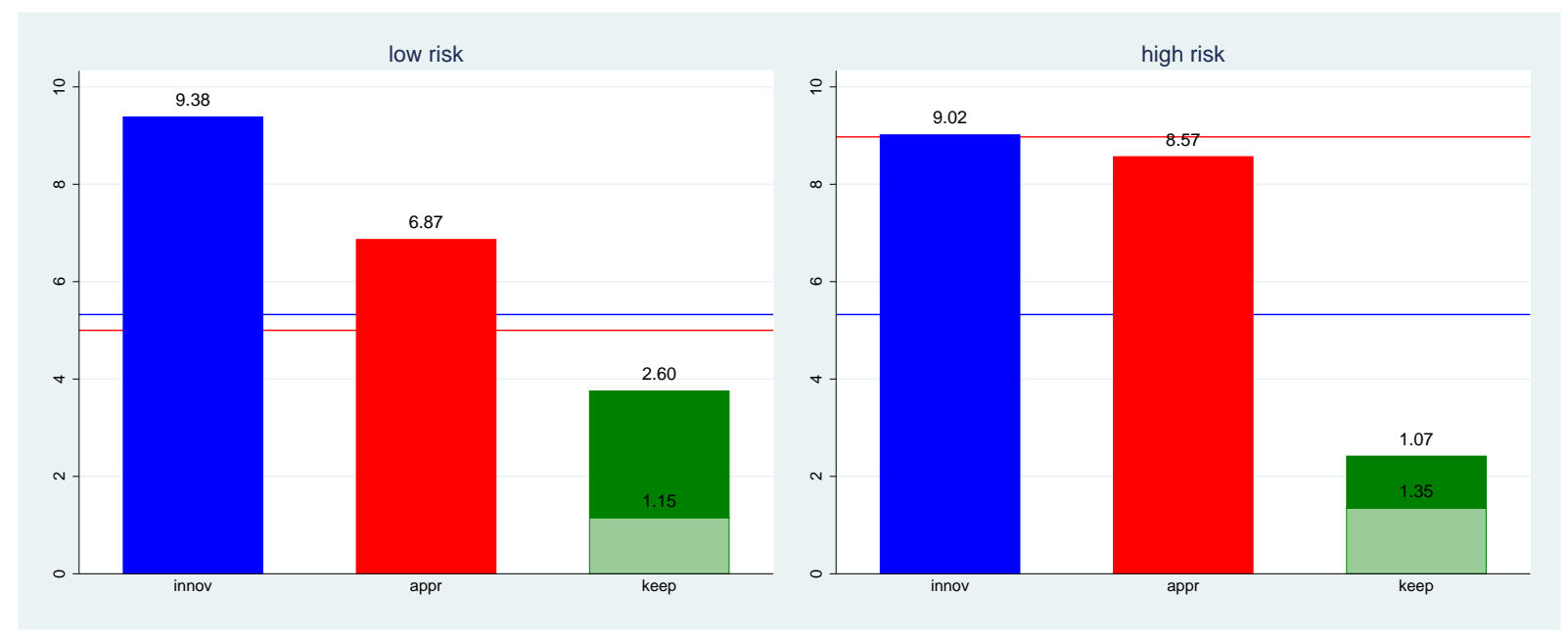

Figure 5

Investment Choices in One-Shot Game

innov: investment into innovation appr: investment into appropriation

light green: endowment kept if partner's project was not successful

dark green: endowment kept if partner's project was successful

lines: point predictions assuming common knowledge of standard preferences

This gives us

Result 1: If innovation and appropriation are costly and risky, the possibility that another participant appropriates one's innovation success does not deter all investment into innovation.

Figure 5 further shows that, in all treatments, investment into appropriation is substantial. Descriptively we thus also clearly refute $\mathbf{H}_{2}$. Participants may have moral compunctions against appropriating the success of foreign efforts. But if they exist, these compunctions are not strong enough to completely deter appropriation. Actually, Figure 5 suggests that moral compunctions have at most a very minor effect. Provided the project of their random partner was successful, very few participants do not try at all to increase their income by appropriation. One sample sign rank tests of the hypothesis that participants invest nothing into appropriation reject at $\mathrm{p}<.0001$ both overall $(\mathrm{N}=104)$ and separately for each treatment $(\mathrm{N}=52$ in both treatments). ${ }^{6}$ This leads to

Result 2: Participants have no reticence to appropriate foreign innovation success.

As Figure 5 shows, descriptively appropriation investment is more pronounced in the High Risk treatment. Descriptively, there is slightly less investment into innovation in the High Risk treatment than in the Low Risk treatment, but investment levels are very close. In the Low Risk treatment, there is less investment into appropriation than into innovation. In the High Risk treatment, the opposite holds true. All of this is in line with $\mathbf{H}_{\mathbf{3}}$ derived from standard economic theory.

6 The sample is confined to cases where the counterpart's project was successful, so that the choice (not) to appropriate is meaningful. 
Yet standard theory is only qualitatively supported. As Figure 5 shows, in the Low Risk treatment, there is more appropriation than predicted by standard theory. This impression is supported by a one sample sign rank test of the point prediction from standard theory $(\mathrm{N}=52, \mathrm{p}$ $<.001){ }^{7}$ By contrast, the level of appropriation does not significantly differ from the theoretical prediction in the High Risk treatment. As suggested by Figure 5, investment into innovation is above the theoretical prediction in both treatments (signrank tests against the point prediction from Table $3, \mathrm{~N}=60, \mathrm{p}<.001$ ).

Figure 5 suggests a further deviation from standard theory: it seems that participants spend too much on innovation and appropriation, and save too little of their endowments, compared with the theoretical prediction. In case the foreign project failed, this impression is difficult to verify statistically since we do not know which fraction of the endowment participants would have wanted to use for appropriation. We do, however, have a clean test of the theoretical prediction if the foreign project was successful. In both treatments, the endowment kept is significantly below the prediction from Table 3 (one-sample sign rank test, both $\mathrm{N}=52, \mathrm{p}<$ .001). Participants overinvest.

Interestingly, in both treatments, innovation investment is closer to the efficient solution than to the Nash prediction. Yet in both treatments, innovation investment is even significantly above the efficient benchmark from Table 3 (one sample signrank tests, $\mathrm{N}=60, \mathrm{p}<.001)^{8}$ This gives us

\section{Result 3: Participants invest more into innovation than predicted by standard theory.}

This result not only rejects the point predictions from standard theory, and hence $\mathbf{H}_{3}$, but also the first predictions derived from inequity aversion $\left(\mathbf{H}_{4}\right)$ and intention based preferences $\left(\mathbf{H}_{5}\right)$.

Mann-Whitney tests show that the treatment effect on appropriation investment is significant, whether we use all data $(\mathrm{N}=120, \mathrm{p}=.0137)$ or confine the sample to cases where the foreign investment was successful $(\mathrm{N}=104, \mathrm{p}=.0040)$. By contrast, the treatment effect on innovation investment is not significant $(\mathrm{p}=.112)$. We thus have

Result 4: Investment into innovation is not sensitive to the degree of risk from appropriation.

This rejects also the second prediction derived from inequity aversion $\left(\mathbf{H}_{4}\right)$ and provides provisional support for the second prediction derived from intention based preferences $\left(\mathbf{H}_{5}\right)$.

\footnotetext{
7 We always test against the exact point predictions, despite the fact that the action space was constrained to integers. If we instead test against point predictions rounded to the nearest integer, results (of course) look very similar. The test is again confined to those cases where the foreign project was successful.

8 Since the Nash prediction coincides with the efficient investment in appropriation, a separate test of this dependent variable against the efficient benchmark is pointless.
} 
Figure 6 reports mean investment into innovation and into appropriation in the repeated game by treatment and period. In both treatments, innovation investments decay over time, but still stay above the theoretical prediction. This holds both overall (signrank test over means per matching group, $\mathrm{N}=10, \mathrm{p}=0.0051$ in both treatments) and for each individual period of the second phase of the experiment $(\mathrm{N}=10, \mathrm{p} \leq 0.022)$. We still do not find a significant treatment effect on innovation investment. ${ }^{9}$ Hence, our findings from the one-shot game are robust to participants' experience.

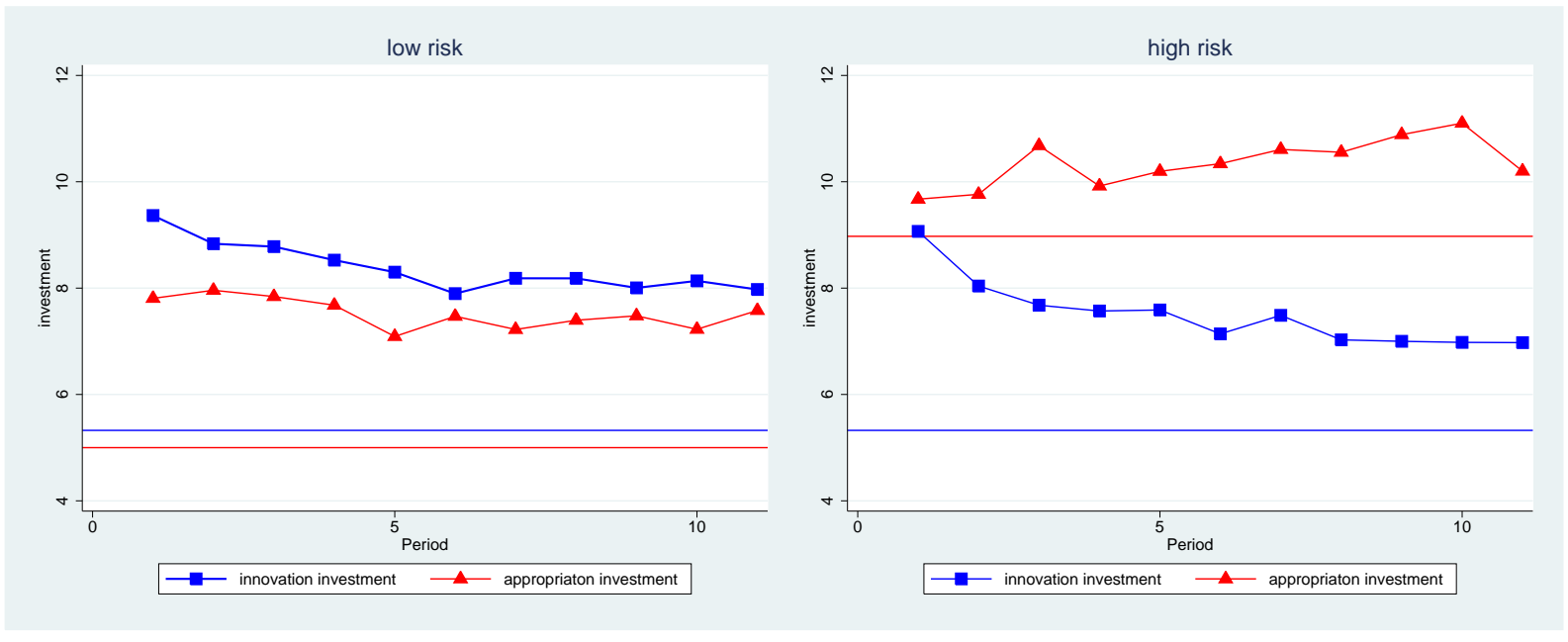

Figure 6

Investment Choices in Repeated Game

appropriation investment: data confined to cases where counterpart's project was successful lines: point predictions assuming common knowledge of standard preferences

The results presented thus far might convey the impression that fairness plays no role in the decision to invest into innovation if innovation success is up to appropriation by an outsider who has not contributed to the cost. The regressions in Table 4 suggest that this impression is premature. The more a participant believes her anonymous counterpart is going to invest into appropriating her innovation, the less she invests (model 1). By contrast, drawing on results of the post-experimental dictator game, the more a participant is willing to give to a recipient who has to earn money that she gets for free, the more she invests into innovation (model 2). ${ }^{10}$ This version of the post-experimental dictator game is closest to the investment case. Generosity in this game indicates that a participant is willing to share even if the recipient is able to earn an income by her own efforts. A final piece of evidence is provided by the repeated game. With repetition, participants may replace beliefs by experience. The more their counterpart from the previous period actually has invested into appropriating their innovation success, the more they react by reducing investment in the current period (model 3). The fact that experiences have the same effect as beliefs makes it unlikely that the effect of beliefs actually

9 In the repeated game, we have data from choices, nested in individuals, nested in matching groups. We capture this data generating process by a mixed effects model with random effects for groups and individuals, $\mathrm{N}=1320$. If we regress innovation investment on treatment, the coefficient is insignificant, $\mathrm{p}=$ .140 .

10 Choices in the remaining three dictator games do not significantly explain investment into innovation. 
results from participants projecting their own behavior onto others. It instead seems that fairness is relevant. Fairness concerns are only not strong enough to deter innovation.

\begin{tabular}{|c|c|c|c|}
\hline & model 1 & model 2 & model 3 \\
\hline Dv & $\begin{array}{l}\text { levels of innovation } \\
\text { investment }\end{array}$ & $\begin{array}{l}\text { levels of innovation } \\
\text { investment }\end{array}$ & $\begin{array}{l}\text { changes in innova- } \\
\text { tion investment }\end{array}$ \\
\hline Periods & 1 & 1 & $2-11$ \\
\hline appropriation belief & $\begin{array}{l}-.254^{*} \\
(.119)\end{array}$ & $\begin{array}{l}-.255^{\star} \\
(.114)\end{array}$ & \\
\hline Generosity & & $\begin{array}{l}.060^{*} \\
(.027)\end{array}$ & \\
\hline $\begin{array}{l}\text { investment of last period's } \\
\text { counterpart in appropriation }\end{array}$ & & & $\begin{array}{l}-.055^{\star * \star} \\
(.011)\end{array}$ \\
\hline Cons & $\begin{array}{l}11.420^{* * *} \\
(1.117)\end{array}$ & $\begin{array}{l}11.043^{* * *} \\
(1.108)\end{array}$ & $\begin{array}{l}.257^{*} \\
(.103)\end{array}$ \\
\hline $\mathrm{N}$ & 120 & 120 & 1200 \\
\hline p model & .0351 & .0036 & $<.0001$ \\
\hline
\end{tabular}

Table 4

Fairness Concerns in LowRisk and HighRisk Treatments

models 1 and 2: OLS with robust standard errors, data from period 1 (all observations are independent)

model 3: linear mixed effects, first differences of choices nested in individuals nested in matching groups, data from all periods (due to first differencing and the use of a lagged explanatory variable, one period is lost)

Hausman test insignificant

standard errors in parenthesis

appropriation belief: how much believes participant others invest into appropriation, provided their counterpart's project is successful

generosity: Fraction of endowment sent by a participant to a recipient who has to earn money while she gets the same amount for free (post-experimental dictator game)

${ }^{* * *} p<.001,{ }^{*} p<.05$

\section{Inequity Aversion versus Intentions}

\section{Design and Procedures}

To better understand this fairness concern and to check the robustness of our finding of overinvestment into innovation, we run two additional treatments. In these treatments, we radicalize the degree of the externality on the anonymous counterpart. In the FullRisk treatment, there is no positive externality at all. Essentially, this is a standard investment game, with the only peculiarity that participants are informed about choices and outcomes of an anonymous partner. In the opposite extreme of the NoRisk treatment, whenever innovation is successful the benefit is automatically shared with an anonymous partner. These two treatments may be interpreted as situations where the cost of investment into appropriation is infinite (FullRisk) or zero (NoRisk). All other elements of the design are held constant.

The additional treatments were run in the same lab, with participants randomly selected from the same subject pool. We had 116 new participants, 60 in the NoRisk treatment, and 56 in the FullRisk treatment. ${ }^{11} 56.9 \%$ of the new participants were female. Mean age was 26.16 years. Participants on average earned $18.14 €$.

114 invited participants did not show up. 


\section{Hypotheses}

If participants hold standard preferences and this is common knowledge, optimal investment into innovation is still given by $\sqrt{g}-1$ or, with the parameters of the experiment, 5.325 Taler. Since the externality is automatically excluded or imposed, to derive this result we need not even consider whether participants have reason to withhold some of their endowment for potential investment into appropriation. Consequently, the part of hypothesis $\mathbf{H}_{\mathbf{3}}$ concerned with innovation investment still applies.

The two additional treatments do, however, give us more scope to discriminate between the two competing behavioural hypotheses. If there is a fairness concern and this concern follows from inequity aversion, we have

$\mathbf{H}_{4 \mathbf{a}}$ : Innovation investment is ordered as follows

FullRisk > HighRisk > LowRisk > NoRisk.

since in the FullRisk treatment there is no externality at all, in the HighRisk treatment it requires a large investment, in the LowRisk treatment a small investment suffices, and in the NoRisk treatment it is certain and automatic. By contrast if there is a fairness concern and this concern follows from intention based preferences, we have

$\mathbf{H}_{5 \mathbf{a}}$ : Innovation investment is ordered as follows

FullRisk $\approx$ NoRisk $>$ HighRisk $\approx$ LowRisk.

In the two additional treatments, the externality does not result from the fact that an outsider decides to appropriate innovation success.

\section{Results}

Figure 7 contrasts average investment choices in the main treatments and the Full/No-Risk treatments. Descriptively, participants invest most into innovation in the treatment where the externality is most pronounced, i.e. in the NoRisk treatment. In both treatments where the counterpart cannot actively try to appropriate innovation success, innovation investment is higher.

The appropriate non-parametric test for the directed hypothesis based on inequity aversion is Jonckheere Terpstra. It is clearly insignificant $(\mathrm{N}=236, \mathrm{p}=.239)$, as is a parametric test that explains investment choices with treatment ordered as suggested by $\mathbf{H}_{\mathbf{4}}$ (OLS, $\mathrm{N}=236$, coef $.158, \mathrm{p}=.588)$. We thus squarely reject a fairness concern resulting from inequity aversion.

By contrast, non-parametrically we do find a significant difference in innovation investment between the HighRisk and the NoRisk treatments (Mann Whitney, $\mathrm{N}=120, \mathrm{p}=.040$ ). Parametrically we also find a significant overall effect of the decision about appropriation being automatic, rather than taken by the appropriator (OLS, $\mathrm{N}=236$, coef $1.472, \mathrm{p}=.011$ ). 
full risk

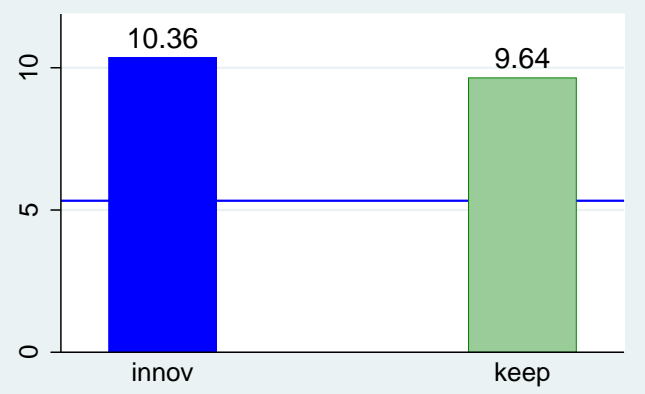

low risk

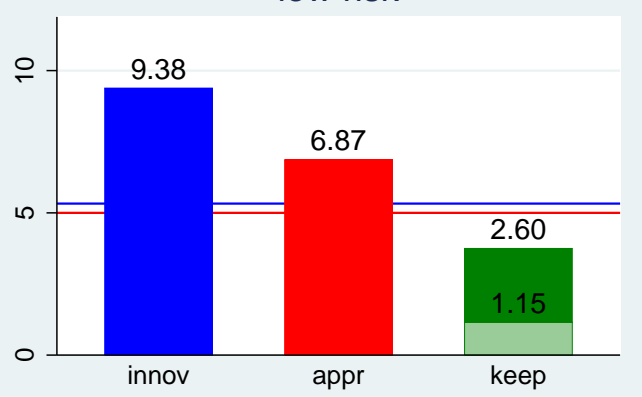

high risk

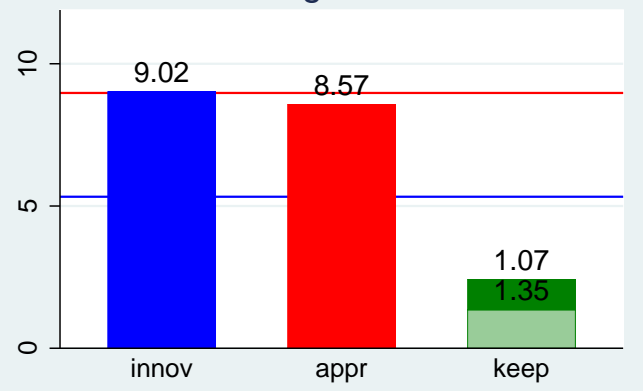

no risk

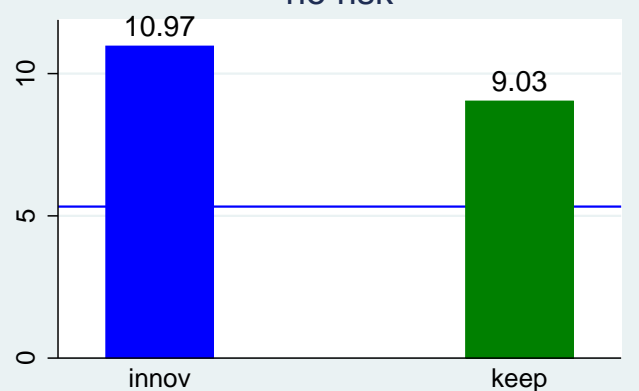

Figure 7

Investment Choices in One-Shot Game, including FullRisk and NoRisk Treatments

innov: investment into innovation

appr: investment into appropriation

light green: endowment kept if partner's project was not successful

dark green: endowment kept if partner's project was successful

lines: point predictions assuming common knowledge of standard preferences

As Figure 8 on investment choices over time demonstrates, in all treatments innovation investment goes down with experience. Nonetheless even in the long run, innovation investment stays high above the prediction assuming common knowledge of standard preferences, i.e. 5.325. Most interestingly for our research question, investment is not at all ordered in the way suggested by inequity aversion. When the effect on relative payoffs is most severe, i.e. in the NoRisk treatment, descriptively investment is in all periods higher than if relative payoffs are completely unaffected, i.e. in treatment FullRisk. 


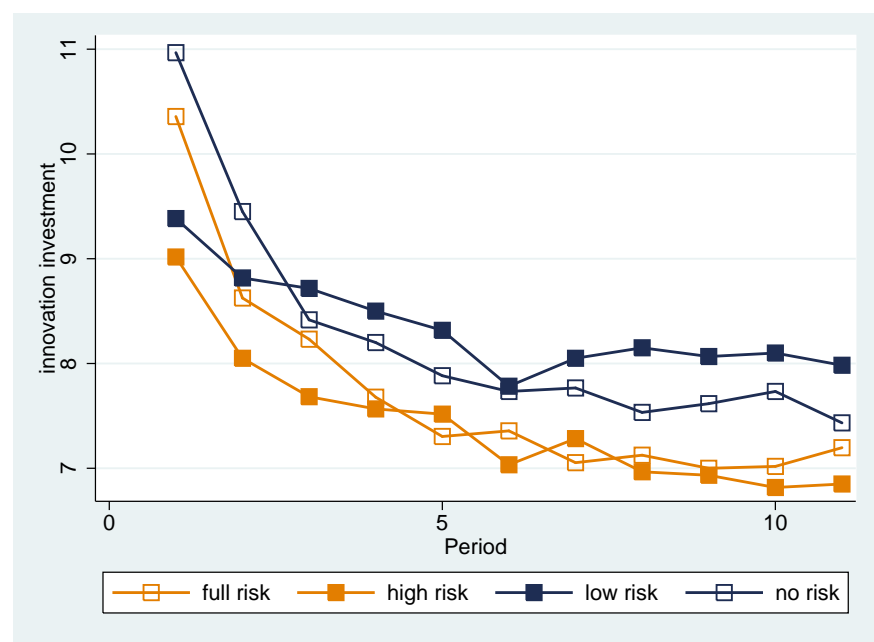

Figure 8

Innovation Investment over Time

Table 5 suggests that the hypothesis derived from intention based preferences also holds in the repeated game. If we capture the nonlinear dynamics of investment choices in all treatments with period and period squared plus interaction terms, we find a strong and highly significant positive effect of appropriation decisions taken away from recipients. The significant negative one-way interaction shows that investment decays faster if appropriation is automatic. But the significant positive two-way interaction shows that the level of investment also stabilises faster. Since it stabilises high above the prediction assuming common knowledge of standard preferences, from a policy perspective this is welcome news. Still, the effect of intentions seems most pronounced with inexperienced subjects.

\begin{tabular}{|c|c|c|c|}
\hline & model 1 & model 2 & model 3 \\
\hline automatic & $\begin{array}{l}.089 \\
(.461)\end{array}$ & $\begin{array}{l}.730 \\
(.484)\end{array}$ & $\begin{array}{l}1.620^{\star *} \\
(.531)\end{array}$ \\
\hline period & $\begin{array}{l}-.199^{\star * \star} \\
(.012)\end{array}$ & $\begin{array}{l}-.147^{\star \star *} \\
(.017)\end{array}$ & $\begin{array}{l}-.440^{* * *} \\
(.074)\end{array}$ \\
\hline automatic ${ }^{*}$ period & & $\begin{array}{l}-.107^{\star * \star} \\
(.024)\end{array}$ & $\begin{array}{l}-.518^{* * \star} \\
(.105)\end{array}$ \\
\hline period $^{2}$ & & & $\begin{array}{l}.024^{\star \star \star} \\
(.006)\end{array}$ \\
\hline automatic $^{*}$ period ${ }^{2}$ & & & $\begin{array}{l}.034^{\star * *} \\
(.009)\end{array}$ \\
\hline cons & $\begin{array}{l}9.084^{* \star \star} \\
(.333)\end{array}$ & $\begin{array}{l}8.769^{* * *} \\
(.340)\end{array}$ & $\begin{array}{l}9.406^{* * *} \\
(.374)\end{array}$ \\
\hline $\mathrm{N}$ & 2596 & 2596 & 2596 \\
\hline p model & $<.0001$ & $<.0001$ & $<.0001$ \\
\hline
\end{tabular}

Table 5

Effect of Appropriation Being Automatic

linear mixed effects, choices nested in individuals nested in matching groups, data from all periods Hausman test insignificant on all models standard errors in parenthesis automatic: treatment $=$ FullRisk or NoRisk ${ }^{* \star *} p<.001,{ }^{\star \star} p<.01$ 
We thus support hypothesis $\mathbf{H}_{\mathbf{5} \mathbf{a}}$ and conclude

Result 5: Investment into innovation is sensitive to willful appropriation by outsiders, but not to the ensuing risk of a smaller relative payoff.

\section{Exploitation}

\section{Design and Procedures}

From a policy perspective, the most important finding is not that fairness matters for the decision to invest into innovation, and that intentions are critical for the fairness assessment. It is much more important that the fairness concern does not stifle innovation. Actually, in all the treatments reported thus far, and in all periods of the repeated game, average investment into innovation was even above the prediction assuming standard preferences. One may wonder whether this result is driven by a feature of the design we have introduced in the interest of identification. We have deliberately isolated the effect of giving outsiders a free lunch. While this design is in line with modeling innovation as a pure public good, it arguably does not capture a further likely fairness concern. In the field, innovators frequently gain from a competitive advantage. In that case, imitation not only means that others benefit from a positive externality. Through competitive pressure, the prize is reduced which the innovator gains for her success. In the final two treatments, we therefore introduce damage from imitation.

Technically we distinguish between gains from innovation $g_{H}$ if there is no appropriation.This parameter is the same as in the LowRisk and HighRisk treatments. We contrast this with a smaller gain from innovation $g_{L}$ in case the innovation is appropriated. This changes payoff to

\begin{tabular}{|l|l|l|}
\hline$\pi_{i}=e-c_{i}-a_{i}+\left(1-\frac{\frac{a_{j}}{y}}{1+\frac{a_{j}}{y}}\right) \frac{c_{i}}{1+c_{i}} g_{H i}+\frac{\frac{a_{j}}{y}}{1+\frac{a_{j}}{y}} \frac{c_{i}}{1+c_{i}} g_{L i}+\beta \frac{\frac{a_{i}}{y}}{1+\frac{a_{i}}{y}} \frac{c_{j}}{1+c_{j}} g_{L j}$ & (6) \\
\hline
\end{tabular}

In the experiment, we set $g_{L}=30$. It thus is $3 / 4$ of the profit from innovation in the LowRisk and HighRisk treatments. Since we would otherwise have to study the strange situation where the appropriator benefits more than the innovator,in the case of successful appropriation we calculate the innovator's and the appropriator's payoff based on the same (lower) payoff $g_{L}$. Successful appropriation thus gives the appropriator $\beta g_{L}=27$.

We deliberately do not add a true market stage. For the reasons discussed when explaining the design of the LowRisk and HighRisk treatments, we would lose experimental control. Moreover between the LowRisk and the LowRiskAppr and between the HighRisk and the HighRiskAppr treatments so many elements would change that we could not interpret treatment effects. For the same reason, we also keep earnings from both projects separate. If my project 
succeeds, but my competitor's project fails, I gain more money, but the other participant does not lose money, compared with the situation where both projects fail. In a competitive market, this would of course be different. But we would again lose the possibility to compare results across treatments. Note that we also keep the sequential structure of the game. At the appropriation stage, innovation decisions are fixed, as is success of innovation.

The additional treatments were run in the same lab, with participants randomly selected from the same subject pool. We had 120 new participants, 60 in the LowAppr treatment, and 60 in the HighAppr treatment. $54.17 \%$ of the new participants were female. Mean age was 25.89 years. Participants on average earned $17.07 €$.

\section{Hypotheses}

Since successful appropriation reduces profit from innovation, optimal innovation investment is conditional on the probability of appropriation. Exploiting the fact that, with the parameters of the experiment, profit maximizing participants have no reason to withhold appropriation investment in the interest of keeping more funds for innovation, we find optimal innovation investment by backward induction. If participants hold standard preferences and this is common knowledge, individually optimal innovation investment is given by

$$
c_{i}^{*}=\frac{\sqrt{\beta g_{L}^{2} y+y \sqrt{\beta g_{L} y}\left(g-g_{L}\right)}-\sqrt{\beta g_{L} y}}{\sqrt{\beta g_{L} y}}
$$

which translates into 4.650 in the LowAppr and 5.007 in the HighAppr treatments. While the generic definition of optimal appropriation investment does not change, point predictions have of course to take into account that appropriation is less profitable. This leads to optimal choices of 4.196 in the LowAppr and 6.432 in the HighAppr treatments. ${ }^{12}$ If participants hold standard preferences and expect other participants to be the same, these are the choices to be expected.

We have already shown that participants are sensitive to the perceived unfairness of appropriating foreign innovation, and that this sensitivity is best explained with perceived intentions. This suggests that participants are even more sensitive if they do not only run the risk of giving others a free lunch, but would even partly lose the gains of their own efforts because others knowingly impinge on their efforts. This leads to

H6: a) Innovation investment is lower if the fact that outsiders appropriate the innovation reduces the innovator's profit from innovation.

b) In that case, innovation investment is below the level predicted by standard theory.

12 Efficient appropriation is 3.123 in LowAppr and 3.038 in HighAppr. Efficient innovation is 6.054 in LowAppr and 5.397 in HighAppr. 


\section{Results}

First-round results look strikingly similar, whether or not appropriation reduces the innovator's profit (Figure 9). If the likelihood of appropriation is small, descriptively there is slightly less innovation and appropriation. If the likelihood of appropriation is high, descriptively there is even more investment into innovation. Yet statistically, we do not find any significant differences, whether we separately compare LowRisk with LowAppr and HighRisk with HighAppr or whether we pool all treatments with and without exploitation. For the one-shot game, we squarely reject both statements of $\mathbf{H}_{\mathbf{6}}$.

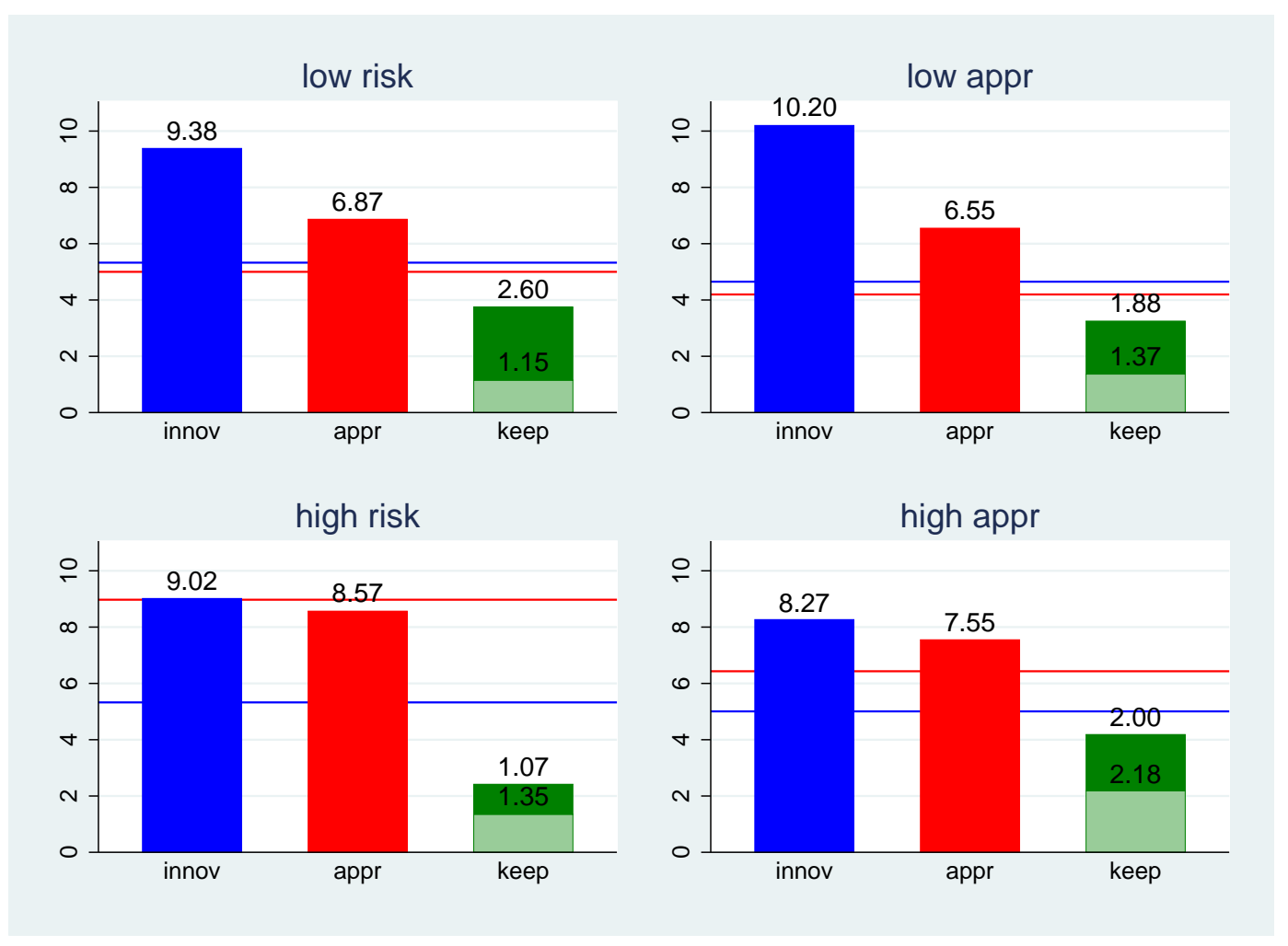

Figure 9

Investment Choices in One-Shot Game, With and Without Exploitation

innov: investment into innovation

appr: investment into appropriation

light green: endowment kept if partner's project was not successfu

dark green: endowment kept if partner's project was successful

lines: point prediction assuming common knowledge of standard preferences

Descriptively, results for the repeated game look even more surprising (Figure 10): if the likelihood of appropriation is high, in all periods investment into innovation is higher if successful appropriation reduces the innovator's profit. By contrast if the likelihood of appropriation is small, descriptively innovation seems unaffected by the risk of exploitation. 


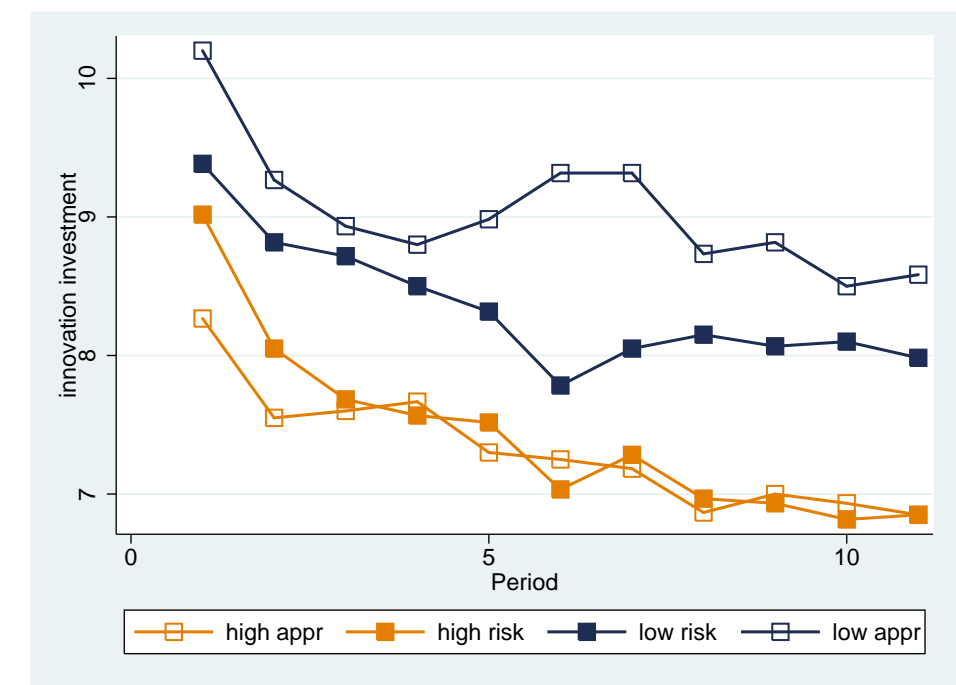

Figure 10

Effect of Exploitation on Innovation Investment over Time

Yet statistically we do not find a main effect of exploitation. All we see is a modification of the downward trend. The significant positive one-way interaction shows that innovation investment decays less rapidly if there is exploitation. The significant negative two-way interaction shows that, with exploitation, the curve is less kinked. ${ }^{13}$

\begin{tabular}{|l|l|}
\hline exploitation & -.313 \\
& $(.533)$ \\
\hline period & $-.440^{* * *}$ \\
& $(.065)$ \\
\hline exploitation ${ }^{*}$ period & $.214^{*}$ \\
& $(.092)$ \\
\hline period $^{2}$ & $.024^{* * *}$ \\
& $(.005)$ \\
\hline exploitation $^{*}$ period & $-.015^{*}$ \\
& $(.007)$ \\
\hline cons & $9.406^{* * *}$ \\
& $(.377)$ \\
\hline $\mathrm{N}$ & 2640 \\
\hline $\mathrm{p}$ model & $<.0001$ \\
\hline
\end{tabular}

Table 6

Effect of Appropriation Reducing Innovator's Profit

linear mixed effects, choices nested in individuals nested in matching groups, data from all periods Hausman test insignificant standard errors in parenthesis exploitation: treatment $=$ LowAppr or HighAppr ${ }^{* * *} p<.001,{ }^{*} p<.05$

In the final step, we check whether exploitation affects process. This turns out not to be the case. Appropriation behaviour is not significantly different. There is no significant difference in beliefs about appropriation either. Participants remain sensitive to these beliefs, and investment choices are explained by their willingness to give in the modified dictator game. Likewise in the repeated game, they remain sensitive to experienced appropriation. Yet all

13 If we further control for the risk of appropriation, i.e. treatment Low, plus all interaction terms, we do not find any significant additional results. The results on the coefficients reported in Table 6 look very similar. 
these results look very similar to the ones reported in Table 4 and, critically, interactions with a dummy for exploitation (i.e. for treatments LowAppr and HighAppr) never turn significant. This gives us our final surprising finding. We reject hypothesis $\mathbf{H}_{\mathbf{6}}$ and conclude:

\section{Result 7: The fact that successful appropriation reduces innovators' profit} does not reduce innovation investment.

\section{Explaining Overinvestment}

The bottom line of our experiment is: participants are sensitive to the fairness problem resulting from others intentionally appropriating the success of their innovations. Yet this sensitivity only moderates the very robust propensity to invest more into innovation than predicted by standard theory. In this concluding, exploratory section we use our data to explain this surprisingly robust observation.

Participants might be striving for efficiency. Our model gives us point predictions for the efficient level of innovation investment, Table 7. In all treatments and periods (except NoRisk in the final period), descriptively innovation investment is even above the efficient level. Except for this treatment, this finding is also supported by statistical tests. ${ }^{14}$

\begin{tabular}{|l|l|c|c|c|c|c|}
\hline \multicolumn{2}{|c|}{} & Nash & Efficient & Period 1 & Periods 2-11 & Period 11 \\
\hline \multirow{4}{*}{ no externality } & NoRisk & 5.325 & 7.718 & 10.967 & 7.977 & 7.433 \\
\cline { 2 - 7 } & LowRisk & 5.325 & 7.062 & 9.383 & 8.248 & 7.983 \\
\cline { 2 - 7 } & HighRisk & 5.325 & 5.932 & 9.017 & 7.270 & 6.850 \\
\cline { 2 - 7 } & FullRisk & 5.325 & 5.325 & 10.357 & 7.459 & 7.196 \\
\hline \multirow{2}{*}{ externality } & LowRiskAppr & 4.650 & 6.054 & 10.200 & 8.925 & 8.583 \\
\cline { 2 - 7 } & HighRiskAppr & 5.007 & 5.397 & 8.267 & 7.220 & 6.850 \\
\hline
\end{tabular}

Table 7

Empirical vs. Theoretical Innovation Investment

empirical data: means per treatment and respective periods

As Figure 9 and Figure 10 demonstrate, the development of innovation investment over time is non-linear. If we capture this non-linearity by period and period squared and interact these regressors with the point prediction for efficient innovation, we find a significant main effect of the efficiency benchmark. Model 1 of Table 8 suggests that participants do indeed strive for efficiency.

14 This is supported by signrank tests of the nul hypothesis that the observed level of innovation investment coincides with the respective point prediction for efficient investment. This hypothesis is rejected for all data $(\mathrm{N}=60, \mathrm{p}<.0001)$ and independently for all treatments but NoRisk $(\mathrm{N}=10, \mathrm{p} \leq .0166)$. All tests work with means per matching group. In all significant tests, most or all means are above the theoretical prediction. 


\begin{tabular}{|c|c|c|c|c|c|}
\hline & model 1 & model 2 & $\begin{array}{l}\text { model } \\
3\end{array}$ & $\begin{array}{l}\text { model } \\
4\end{array}$ & $\begin{array}{l}\text { model } \\
5\end{array}$ \\
\hline efficient investment & $\begin{array}{l}.626^{\star} \\
(.250)\end{array}$ & & $\begin{array}{l}.548^{*} \\
(.265)\end{array}$ & & $\begin{array}{l}-.180 \\
(.348)\end{array}$ \\
\hline period & $\begin{array}{l}.144 \\
(.305)\end{array}$ & & $\begin{array}{l}.298 \\
(.360)\end{array}$ & & $\begin{array}{l}-.019 \\
(.508)\end{array}$ \\
\hline efficient investment ${ }^{*}$ period & $\begin{array}{l}-.109^{*} \\
(.048)\end{array}$ & & $\begin{array}{l}-.091 \\
(.057)\end{array}$ & & $\begin{array}{l}.058 \\
(.088)\end{array}$ \\
\hline period $^{2}$ & $\begin{array}{l}-.018 \\
(.025)\end{array}$ & & $\begin{array}{l}-.027 \\
(.027)\end{array}$ & & $\begin{array}{l}.004 \\
(.035)\end{array}$ \\
\hline $\begin{array}{l}\text { efficient investment }{ }^{*} \\
\text { period }^{2}\end{array}$ & $\begin{array}{l}.008^{*} \\
(.004)\end{array}$ & & $\begin{array}{l}.006 \\
.004) \\
(.004)\end{array}$ & & $\begin{array}{l}1.004 \\
.004 \\
(.006)\end{array}$ \\
\hline $\begin{array}{l}\text { investment of last period's partner into innova- } \\
\text { tion }\end{array}$ & & $\begin{array}{l}.094^{* * *} \\
(.010)\end{array}$ & $\begin{array}{l}.069^{* * *} \\
(.010)\end{array}$ & $\begin{array}{l}.077^{* \star *} \\
(.016)\end{array}$ & $\begin{array}{l}.867^{\star *} \\
(.277)\end{array}$ \\
\hline lagged own investment into innovation & & & & $\begin{array}{l}.713^{\star * \star} \\
(.141)\end{array}$ & $\begin{array}{l}.075^{* * *} \\
(.019)\end{array}$ \\
\hline cons & $\begin{array}{l}5.911^{\star \star \star} \\
(1.580)\end{array}$ & $\begin{array}{l}7.090^{\star \star \star} \\
(.197)\end{array}$ & $\begin{array}{l}4.962^{\star \star} \\
(1.672)\end{array}$ & $\begin{array}{l}1.482 \\
(1.049)\end{array}$ & $\begin{array}{l}.224 \\
(2.211)\end{array}$ \\
\hline $\mathrm{N}$ & 3916 & 3560 & 3560 & 3560 & 3560 \\
\hline p model & $<.0001$ & $<.0001$ & $<.0001$ & $<.0001$ & $<.0001$ \\
\hline
\end{tabular}

Table 8

Explaining Overinvestment

models 1 - 3: linear mixed effects, choices nested in individuals nested in matching groups

Hausman test insignificant on all models

models 4 - 5: systems Arellano Bond, using only lag 3, standard errors clustered for matching groups

${ }^{\star * *} p<.001,{ }^{* *} p<.01,{ }^{*} p<.05,{ }^{+} p<.1$

A competing explanation is a competition motive. Every period participants learn how much their random counterpart has invested into innovation. Model 2 of Table 8 shows that this also significantly predicts how much they will themselves invest in the next period. Model 3 shows that both explanations also hold, conditional on the other.

Yet the random partner's innovation investment might just be a proxy for the overall investment level in the experiment. Model 4 shows that this is not the case. In this model we control for the participant's own investment into innovation in the previous period. ${ }^{15} \mathrm{We}$ still find a significant positive effect of investment by last period's partner. Yet if we now bring efficiency back in, it no longer has explanatory power (model 5). This suggests that the actual driving force is the competition motive, not a desire for efficiency.

\section{Conclusion}

In the policy debate, often the impression is conveyed that tight legal protection is a precondition for the willingness of individuals or firms to take the risk of innovation. Arguably, from a behavioral perspective, the problem is more pronounced. If someone else exploits the success of my efforts, this violates the fairness norm of desert. I am the sucker, which violates distributional fairness. The chilling effect should be even more pronounced if imitation deprives me of my competitive advantage.

15 This of course constitutes a dynamic panel. Such panels are known to be inconsistent. We therefore revert to instrumentation. Since we also want to see the main effect of risk aversion, we use the systems (GMM) estimator. 
To test these conjectures, we ran a lab experiment. Overall, we do not find support for the concern. Qualitatively, participants behave as predicted by standard economic theory. They understand that the setting calls for splitting their budget between innovation and appropriation, reacting to the comparative profitability of both investments. Fairness also plays the expected role. The more participants think or experience that others appropriate their innovations, the less they invest. The less they are sensitive to fairness of desert, the more they invest. Yet in the experiment none of this translates into a policy problem. Participants invest substantially more into innovation than predicted by standard theory. The data suggest that this result can partly be explained by a competition motive. Participants do not want to fall behind the innovation efforts of their peers. Actually this motive is so strong that innovation investment stays at the same level if successful imitation reduces innovators' profit. Participants invest even more into innovation if appropriation is automatic. This suggests that the fairness problem does not result from comparing payoff, but from perceived intentions.

We do find more appropriation than predicted by standard theory, though. This is unwanted from a welfare perspective. But the deadweight loss exclusively results from the fact that participants save too little. Innovation is not deterred. To the contrary, we not only find more innovation than standard theory predicts, but even more innovation than would be welfare maximizing. Participants overinvest into both activities.

Experiments are not meant to map reality. They are tools for identifying causal effects. Consequently, one should be cautious when drawing policy conclusions. Most patent applications are filed for inventions made by the employees of a firm. Different legal orders use different techniques to make sure that the employer may exploit the invention. We test student subjects who decide on their own. We do not mean to claim that firms behave the same way as individuals. Firms are highly aggregate, institutionally embedded, historically entrenched corporate actors (Engel 2010). Yet ultimately, it is not possible to implement firms in the lab. One may have groups decide instead of individuals, or agents on behalf of principals. But it is still a long way from here to a true corporate actor. In principle, field experiments with firms are a possibility. But even if firms were to agree, it would be next to impossible to fix the probability of success or appropriation. While information about patent applications and patents granted is publicly available, innovative activity that does not lead to patent filing is much harder to observe in the field. We thus trade some aspects of external validity for experimental control. We deem the price acceptable for two reasons: while fairness preferences, are not likely to be in firms exactly as in individuals, ultimately individuals have to decide on behalf of firms, and will be influenced by these behavioral traits. Moreover, in the legal discourse justifying intellectual property, the individual innovator is the regulative model. Even if, in economic terms, the ultimate owner of the intellectual property right is the firm, this requires an explicit transfer of a right that, legally, originates in the individual. And in the field, individuals marketing their own innovation are not uncommon. To them, our results directly apply.

Policymakers might find it important to learn that the cost and the risk of appropriation matter. If appropriation is not free of charge, and if its success is uncertain, innovation is not de- 
terred, even if it is not protected by intellectual property rights. If the law nonetheless grants a monopoly, this may lead to a welfare loss, provided the additional benefit from giving the innovator even stronger incentives is smaller than the resulting deadweight loss. Policymakers might still want to do something about excessive appropriation, both on efficiency grounds and since innovators dislike it. Yet if one may extrapolate from the lab to the field, the main concern in the policy debate is not valid. If innovation is not legally protected, this does not stifle innovation, as long as appropriation is also costly and risky. 


\section{References}

Aghion, Philippe, Christopher Harris, Peter Howitt and John Vickers (2001). "Competition, Imitation and Growth with Step-by-Step Innovation." Review of Economic Studies 68(3): 467-492.

BäKer, Agnes, Werner Güth, Kerstin Pull and Manfred Stadler (2011). Creativity, Analytical Skills, Personality Traits, and Innovation Game Behavior in the Lab. An Experiment http://pubdb.wiwi.uni-jena.de/pdf/wp_2011_056.pdf.

BesSEN, JAMES E. and ERIC MASKIN (2009). "Sequential Innovation, Patents, and Imitation." Rand Journal of Economics 40(4): 611-635.

Bolton, Gary E. and Axel OcKenfels (2000). "ERC: A Theory of Equity, Reciprocity and Competition." American Economic Review 90: 166-193.

Cantner, Uwe, Werner Güth, Andreas Nicklisch and Torsten Wieland (2009). "Competition in Product Design. An Experiment Exploring Innovation Behavior." Metroeconomica 60: 724-752.

ChARNESS, GARY (2000). "Self-Serving Cheap Talk. A Test of Aumann's Conjecture." Games and Economic Behavior 33: 177-194.

Cimoli, Mario, Giovanni Dosi, Roberto Mazzoleni and Bhaven Sampat (2011). Innovation, Technological Change and Patents in the Development Process. A Long Term View http://www.lem.sssup.it/WPLem/files/2011-06.pdf.

Cohen, Wesley M., Akira Goto, Akiya Nagata, Richard R. Nelson and John P Walsh (2002). "R\&D Spillovers, Patents and the Incentives to Innovate in Japan and the United States." Research Policy 31(8-9): 1349-1367.

Cohen, Wesley M., Richard R. Nelson and John P Walsh (2000). Protecting their Intellectual Assets. Appropriability Conditions and Why US Manufacturing Firms Patent (or not)

http://www.business.otago.ac.nz/ECON/courses/econ432/Secure/NBER_patent_paper.pdf.

Cornes, Richard and Todd SANDLER (1996). The Theory of Externalities, Public Goods and Club Goods. Cambridge, Cambridge University Press.

Darai, Donja, Jens Großer and Nadja Trhal (2009). Patents vs. Subsidies. A Lab Experiment http://www.econ.uzh.ch/faculty/darai/publications/wp0905.pdf.

Davidson, Carl and Paul S. Segerstrom (1998). "R\&D Subsidies and Economic Growth." Rand Journal of Economics 29: 548-577. 
Deck, CARY A. and Nisvan ERKal (2012). "An Experimental Analysis of Dynamic Incentives to Share Knowledge." Economic Inquiry ***: ***.

Diduch, AMY MCCORMICK (2010). "Patents and R\&D. A Classroom Experiment." International Review of Economic Education 9(2): 67-83.

Engel, Christoph (2010). "The Behaviour of Corporate Actors. A Survey of the Empirical Literature." Journal of Institutional Economics 6: 445-475.

Engel, Christoph (2011). "When is Intellectual Property Needed as a Carrot for Innovators?" Journal of Competition Law and Economics 7: 277-299.

FARIA, Pedro DE and Wolfgang SofKA (2010). "Knowledge Protection Strategies of Multinational Firms-A Cross-country Comparison." Research Policy 39: 956-968.

Fehr, ERnst and Klaus M. Schmidt (1999). "A Theory of Fairness, Competition, and Cooperation." Quarterly Journal of Economics 114: 817-868.

FISCHBACHER, URS (2007). "z-Tree. Zurich Toolbox for Ready-made Economic Experiments." Experimental Economics 10: 171-178.

Gill, David and Rebecca Stone (2010). "Fairness and Desert in Tournaments." Games and Economic Behavior 69(2): 346-364.

GREINER, BEN (2004). An Online Recruiting System for Economic Experiments. Forschung und wissenschaftliches Rechnen 2003. Kurt Kremer und Volker Macho. Göttingen: 79-93.

Grossman, Gene M. and Elhanan Helpman (1992). Innovation and Growth in the Global Economy, MIT Press.

HARABI, NAJIB (1994). Appropriability of Technical Innovations. An Empirical Analysis

Hardin, GarretT (1968). "The Tragedy of the Commons." Science 162: 1243-1248.

Heller, Michael A. and Rebecca Eisenberg (1998). "Can Patents Deter Innovation? The Anticommons in Biomedical Research." Science 280(5364): 698-701.

Holt, Charles A. and Susan K. Laury (2002). "Risk Aversion and Incentive Effects." American Economic Review 92: 1644-1655.

IsAaC, R. MARK and StAnley S. ReynoldS (1992). "Schumpeterian Competition in Experimental Markets." Journal of Economic Behavior and Organization 17(1): 59-100.

KAPLOW, LouIS (1984). "The Patent-Antitrust Intersection." Harvard Law Review 97: 18131892. 
Lemley, Mark A. and Carl Shapiro (2005). "Probabilistic Patents." Journal of Economic Perspectives 19(2): 75-98.

Levin, Richard C., Alvin K. Klevorick, Richard R. Nelson, Sidney G. Winter, RICHARD GILBERT and ZVI GRILICHES (1987). "Appropriating the Returns from Industrial Research and Development." Brookings Papers on Economic Activity: 783831.

Liebrand, Wim B. and CharlesG. McClintock (1988). "The Ring Measure of Social Values. A Computerized Procedure for Assessing Individual Differences in Information Processing and Social Value Orientation." European Journal of Personality 2: 217-230.

Mansfield, Edwin, Mark Schwartz and SAmuel Wagner (1981). "Imitation Costs and Patents. An Empirical Study." Economic Journal 91: 907-918.

MAZAR, NinA, On Amir and Dan Ariely (2008). "The Dishonesty of Honest People. A Theory of Self-Concept Maintenance." Journal of Marketing Research 45(6): 633-644.

Menell, Peter S. and SuZAnne Scotchmer, Eds. (2005). Intellectual Property.

Montero, Maria, Martin Sefton and Ping Zhang (2008). "Enlargement and the Balance of Power. An Experimental Study." Social Choice \& Welfare 30: 69-87.

Mukoyama, ToshiHIKo (2003). "Innovation, Imitation, and Growth with Cumulative Technology." Journal of Monetary Economics 50(2): 361-380.

RABIN, MATTHEW (1993). "Incorporating Fairness into Game Theory and Economics." American Economic Review 83: 1281-1302.

Raustiala, Kal and Christopher Sprigman (2012). The Knockoff Economy: How Imitation Sparks Innovation, Oxford University Press, USA.

Sbriglia, PAtrizia and JOHN D. Hey (1994). "Experiments in Multi-stage R\&D Competition." Empirical Economics 19(2): 291-316.

Segerstrom, Paul S. (1991). "Innovation, Imitation, and Economic Growth." Journal of Political Economy: 807-827.

SELTEN, REINHARD (1967). Die Strategiemethode zur Erforschung des eingeschränkt rationalen Verhaltens im Rahmen eines Oligopolexperiments. Beiträge zur experimentellen Wirtschaftsforschung. Ernst Sauermann. Tübingen, Mohr: 136-168.

Silipo, Damiano B. (2005). "The Evolution of Cooperation in Patent Races. Theory and Experimental Evidence." Journal of Economics 85(1): 1-38. 
SuETENS, SigRID (2005). "Cooperative and Noncooperative R\&D in Experimental Duopoly Markets." International Journal of Industrial Organization 23: 63-82.

SuETENS, SigRID (2008). "Does R\&D Cooperation Facilitate Price Collusion? An Experiment." Journal of Economic Behavior \& Organization 66: 822-836.

ULLBERG, ESKIL (2010a). Coordinating Inventive and Innovative Decisions through Markets with Prices. A Experimental Study of Patent Markets with Transparent Prices http://hj.se/download/18.3bf8114412e804c78638000142/WP2010-14+.pdf.

UlLberG, EsKIL (2010b). From Personal to Impersonal Exchange in Ideas. An Experimental Study of Patent Markets with Transparent Prices https://hj.se/download/18.3bf8114412e804c78638000141/WP2010-13+.pdf.

United States Government ACCountabiLity OfFice (2010). Observations on Efforts to Quantiy the Economic Effects of Counterfeit and Pirated Goods http://www.gao.gov/assets/310/303057.pdf.

ZiZZO, DANIEL JOHN (2002). "Racing with Uncertainty. A Patent Race Experiment." International Journal of Industrial Organization 20: 877-902. 


\section{Appendix: Instructions}

[The following are the instructions for the HighRisk treatment. For the LowRisk treatment, replace the second table and the second graph as in Figure 3. For changes in the HighAppr, LowAppr, FullRisk and NoRisk treatments, see footnotes.]

Welcome to our experiment!

If you read the following instructions carefully, you can earn a substantial amount of money, depending on your decisions. It is therefore very important that you read these instructions carefully.

During the experiment, any communication with the other participants is strictly forbidden. Disobeying this rule will lead to exclusion from the experiment and from all payments. If you have any questions, please raise your hand. We will come to you.

In most parts of the experiment, we shall speak not of Euro, but instead of Taler. In these parts of the experiment, your income is hence initially calculated in Taler. The total Taler amount you earn during the experiment is converted into Euro at the end, at the following rate, unless stated otherwise:

\section{Taler = 2 Eurocent}

At the end, you will be paid your total earnings from the experiment in cash and in Euro. Your earnings will not be less than 4 Euro.

The experiment consists of six parts. We will begin by explaining the first part. You will receive the instructions for the other parts afterwards. Payments from all later parts do not depend on your decisions or income from earlier parts of the experiment.

\section{First Part of the Experiment}

In this part of the experiment, you are randomly matched with a second participant. You are not told which participant this is.

The first part of the experiment consists of two steps.

You will receive an endowment of 20 Taler. You may keep this endowment in its entirety or in part. Alternatively, you may also use all or part of your endowment ${ }^{16}$ in the first or the second step. In the second step, however, you can only use the Taler that you have retained in the first step.

16 In the FullRisk and NoRisk treatments, the rest of the paragraph reads "in the first step." 


\section{Step One}

In the first step, you can invest Taler in a project. If the project is successful, you will receive 40 Taler. ${ }^{17}$ The more Taler you invest, the more likely it is for the project to be successful. The following table shows you with which probability the project will be successful if you invest a certain number of Taler in the project. The figure is a graphic depiction of the same context.

\begin{tabular}{|l|l|}
\hline Taler Invested & $\begin{array}{l}\text { Probability of Success, } \\
\text { in \% }\end{array}$ \\
\hline 1 & 50.0 \\
\hline 2 & 66.7 \\
\hline 3 & 75.0 \\
\hline 4 & 80.0 \\
\hline 5 & 83.3 \\
\hline 6 & 85.7 \\
\hline 7 & 87.5 \\
\hline 8 & 88.9 \\
\hline 9 & 90.0 \\
\hline 10 & 90.9 \\
\hline 11 & 91.7 \\
\hline 12 & 92.3 \\
\hline 13 & 92.9 \\
\hline 14 & 93.3 \\
\hline 15 & 93.8 \\
\hline 16 & 94.1 \\
\hline 17 & 94.4 \\
\hline 18 & 94.7 \\
\hline 19 & 95.0 \\
\hline 20 & 95.2 \\
\hline
\end{tabular}

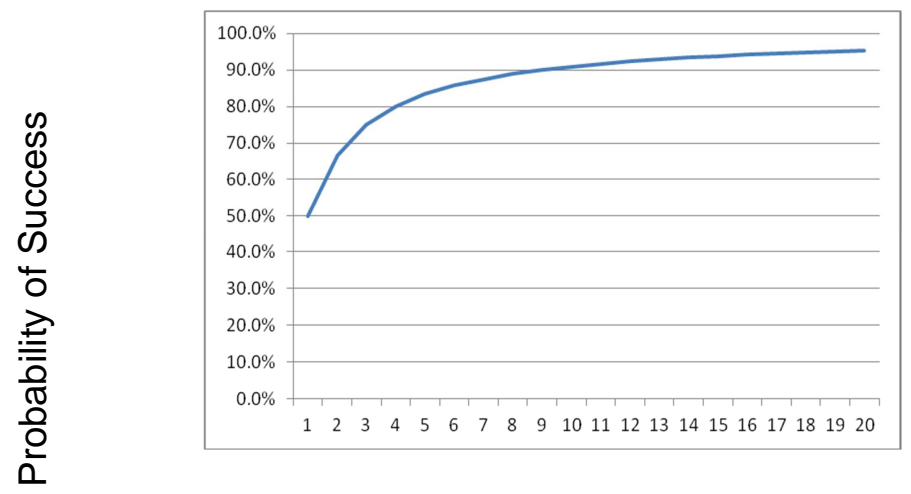

Taler Invested

The participant assigned to you has exactly the same task as you do. This participant also decides, in the first step, how many Taler to invest in his or her project.

17 In the LowAppr and HighAppr treatments, this sentence reads: „If the project is successful, you will receive 30 or 40 Taler. It depends on the second step of the experiment whether you receive 30 or 40 Taler in case you are successful". 


\section{Step Two}

In the second step, you are told whether your project from step one has been successful. At the same time, you are told how many Taler the participant with whom you have been randomly matched invested in the project in step one, and whether this participant's project (referred to henceforth as the "foreign project") has been successful. Similarly, this participant is told how many Taler you invested in your project, and whether your project has been successful. ${ }^{18}$

In this second step, you have the opportunity to use the success of the project of the participant assigned to you for your own means. In order to do this, you may invest a maximum of all Taler remaining at your disposal from your endowment. You will receive a maximum of $90 \%$ of the winnings the other participant has made from his or her project in step one. In turn, the participant assigned to you has the opportunity to use the success of your project from step one for his or her purposes. Neither the success of your own project from step one nor the success of the foreign project from step one is affected by these decisions. Participants hence keep their respective winnings from step one in their entirety. ${ }^{19}$

The more Taler you invest, the more likely it is that you will gain from using the foreign project (assuming the foreign project was successful). Every Taler invested thus increases the likelihood that you will receive winnings from using the foreign project, and that will be $90 \%$ of the winnings of the foreign project. The following table shows you with which possibility you will receive winnings from using the foreign project, if you invest a certain amount of Taler. The figure is a graphic depiction of the same context.

18 In the FullRisk treatment, the instructions directly go on with the word "total earnings" on the next page. In the NoRisk treatment, after this paragraph a new paragraph follows: "If the project of the participant assigned to you has been successful, you receive additional $\mathbf{3 6}$ Taler. If your project has been successful, the participant assigned to you receives additional 36 Taler."

19 In the LowAppr and HighAppr treatments, the two sentences in bold font are replaced by "If you successfully use the project of the participant assigned to you for your purposes (i.e. if you receive a payoff from using the project), this participant receives a payoff of 30 Taler for her project from step one. If you do not successfully use this participant's project for your purposes, she receives a payoff of $\mathbf{4 0}$ Taler for her project (always conditional on the project of the participant assigned to you in step one being successful). Likewise you receive a payoff of 30 Taler for your project from step one if the participant assigned to you successfully uses your project for her purposes (i.e. receives a payoff from the project). If this participant does not successfully use your project for her purposes, you receive $\mathbf{4 0}$ Taler for your project from step one (again on the condition that your project from step one was successful)." 


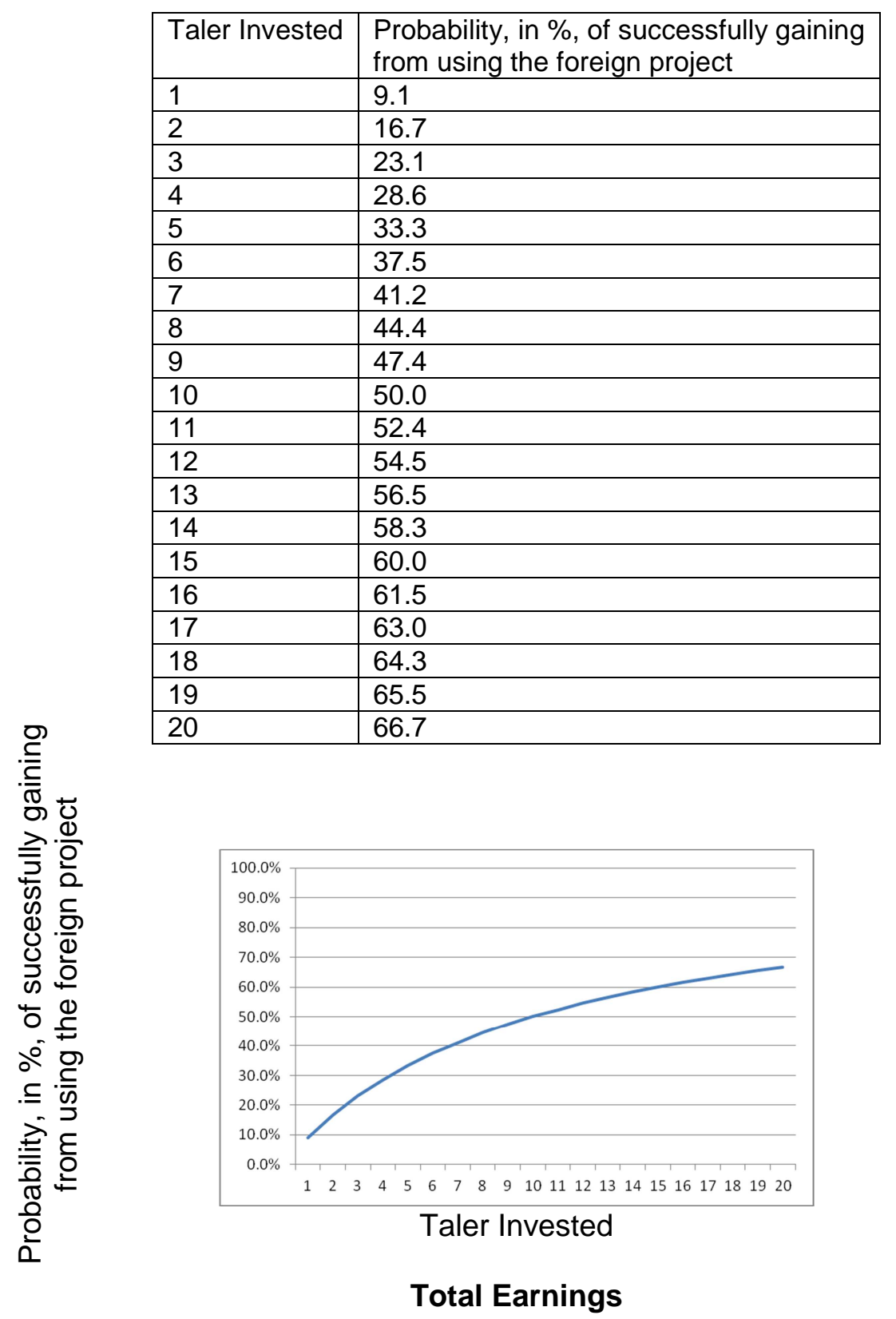

Your total earnings from this part of the experiment add up as follows:

Your total earnings $=$ Your endowment

- Investment in your project

+ Winnings from your project

(first step)

- Investment in using foreign project

+ Winnings from using foreign project (second step) ${ }^{20}$

20 In the FullRisk treatment this reads:

"Your total earnings $=$ Your endowment

- Investment in your project

+ Winnings from your project

(first step)“"

In the NoRisk treatment this reads:

"Your total earnings $=$ Your endowment

- Investment in your project

+ Winnings from your project

(first step)

+ Winnings from using foreign project (second step)" 


\section{Second Part of the Experiment ${ }^{21}$}

This part of the experiment follows from the first part. We would like to hear your opinion. What do you think about the following?

1. In your opinion, what percentage of participants invested, in step two, in using the success of the project of the participant assigned to them for themselves, assuming that this project was successful in step one?

2. In your opinion, how many Taler have these participants invested on average in step two? I.e., how many Taler have the participants who decided to use the success of the project of the participant assigned to them invested on average, assuming that the project of the participant assigned to them was successful in step one?

You will receive 50 Taler if your estimate in question 1 is no further away than $5 \%$ from the actual percentage. You will receive an additional 50 Taler if your estimate in question 2 is no further away than 1 Taler from the actual average amount invested.

We will inform you about the results from this part of the experiment at the end of the experiment.

\section{Third Part of the Experiment}

The third part of the experiment is exactly the same as the first part of the experiment. Only now, a new participant is randomly assigned to you ten times. Both participants make the decisions we have described in the first part of the instructions. Participants are randomly matched anew for each of the ten rounds.

[Fourth Part of the Experiment: Holt and Laury 2002 with standard instructions at the computer screen]

\section{Fifth Part of the Experiment}

In this part of the experiment, you will be randomly matched once again with another participant. At the end of this part of the experiment, the computer will be used for a second draw to determine whether you will have the active or the passive role in this part of the experiment. We ask all participants to decide how they intend to behave in case they are given the active role. Participants with the active role have the opportunity to send any part of their income from this part of the experiment to the passive participant. If you choose $0 \%$, you retain your entire income for yourself. If you choose $100 \%$, you send your entire income to the passive participant. You may choose any percentage between 0 and $100 \%$.

21 This part of the experiment is missing in treatments FullRisk and NoRisk. 
We will ask you to make a binding decision for the four different situations that are described in the following table:

\begin{tabular}{|c|c|l|l|}
\hline \multicolumn{2}{|c|}{} & \multicolumn{2}{c|}{ Passive role } \\
\cline { 3 - 4 } Active role & No income & Income earned \\
\hline & $\begin{array}{c}\text { Income } \\
\text { given }\end{array}$ & & \\
\cline { 2 - 4 } & $\begin{array}{c}\text { Income } \\
\text { earned }\end{array}$ & & \\
\hline
\end{tabular}

Which of the four situations actually occurs is also determined by a random draw (all situations are equally probable). If you have the active role, and once the income is "given", you will receive an advance income of 125 Taler. If you have one of the two roles and the income has to be "earned", you will be shown 5 tables like the following one:

\begin{tabular}{|l|l|l|}
\hline 4.67 & 4.81 & 3.05 \\
\hline 5.82 & 5.06 & 4.28 \\
\hline 6.36 & 5.19 & 4.57 \\
\hline
\end{tabular}

Your task is to find the two cells that add up to 10. In each table, there are only two cells that add up to 10. You have as much time for this task as you require. For every task that you have solved correctly, you will receive an income of 25 Taler (hence a possible total of 125 Taler). If you have the passive role and are in one of the "no-income" situations, you will not receive any income of your own.

However, you will only receive a payoff from this part and all other parts of the experiment once you have correctly solved all 5 tasks.

The earnings for participants with active and passive roles are hence as follows in the four situations:

\begin{tabular}{|c|c|c|c|}
\hline & \multicolumn{2}{|c|}{ Passive role } \\
\hline & & No income & Income earned \\
\hline \multirow{4}{*}{ Active role } & \multirow[t]{2}{*}{ Income given } & $\begin{array}{c}\text { Active role: } \\
\text { 125 Taler income } \\
\text { - Taler sent }\end{array}$ & $\begin{array}{l}\text { Active role: } \\
125 \text { Taler income } \\
\text { - Taler sent }\end{array}$ \\
\hline & & $\begin{array}{c}\text { Passive role: } \\
0 \text { Taler income + Taler received }\end{array}$ & $\begin{array}{l}\text { Passive role: } \\
125 \text { Taler income + Taler received }\end{array}$ \\
\hline & \multirow[t]{2}{*}{$\begin{array}{l}\text { Income } \\
\text { earned }\end{array}$} & $\begin{array}{l}\text { Active role: } \\
125 \text { Taler Einkommen } \\
\text { - Taler sent }\end{array}$ & $\begin{array}{c}\text { Active role: } \\
125 \text { Taler income } \\
\text { - Taler sent }\end{array}$ \\
\hline & & $\begin{array}{c}\text { Passive role: } \\
0 \text { Taler income + Taler received }\end{array}$ & $\begin{array}{c}\text { Passive role: } \\
125 \text { Taler income + Taler received }\end{array}$ \\
\hline
\end{tabular}

This part of the experiment once again operates with the exchange rate of 1 Taler $=2$ Eurocent. 